\title{
A estética do jardim na literatura: Delille, Goethe e Poe
}

The aesthetics of garden in Literature: Delille, Goethe and Poe

hitps://doi.org/10.1590/1982-02672020v28e49

\section{ESDRAS ARAUJO ARRAES²}

http:/ / orcid.org/0000-0003-0374-740 1

Universidade de São Paulo / São Paulo, SP, Brasil

RESUMO: $\bigcirc$ artigo reflete sobre os discursos literários e visuais do jardim e da natureza que há em determinadas obras dos poetas e escritores Jacques Delille, Johann Wolfgang von Goethe e Edgar Allan Poe. Inicialmente apresenta-se uma bibliografia atual dedicada a interpretar as imbricações entre a literatura e a jardinagem para, em seguida, abordar a representação dos jardins no poema "Os jardins" (1782) de Delille, no romance As afinidades eletivas (1809) de Goethe e em dois contos de Poe - O domínio de Arnheim ou o jardim-paisagem (1842) e A cottage de Landor. Um caminhante no domínio de Arnheim (1 846). A narrativa do texto considera as duas formas de jardins do século XVIII - a de "gosto francês" e o "jardim-paisagem" - como alegorias de diferentes cosmovisões, as quais dizem respeito, sobretudo, à maneira como o ser humano se relaciona com seus pares e com a natureza. A metodologia emprega uma abordagem interdisciplinar com foco na estética, na literatura, na história da arte e na arquitetura.

PALAVRAS-CHAVE: Arte. Estética. Jardim. Literatura. Natureza. Paisagem.

ABSTRACT: The article reflects on literary discourses of garden and nature there are in determined works written by Jacques Delille, Johann Wolfgang von Goethe and Edgar Allan Poe. It initially presents a current bibliographic sources dedicated to interpret the overlay between literature

\begin{abstract}
1. Este artigo é um dos resultados de uma pesquisa de pós-doutorado com bolsa FAPES P (processo 2018/19708-7), realizada na Universidade Livre de Berlim (FUB) sob a supervisão do Prof. Dr. Michael Gamper.

2. Graduado em Arquitetura e Urbanismo pela Universidade Federal de Pernambuco (UFPE). Mestre em Arquitetura e Urbanismo pela Faculdade de Arquitetura e Urbanismo da Universidade de São Paulo (FAUUSP) e doutor em Ciências pela mesma instituição. Foi pesquisador visitante no Centro de Humanidades (CHAM) da Universidade Nova de Lisboa. Concluiu pesquisa de estágio doutoral na Universidade do Algarve. Realizou estágio de pós-doutorado na Freie Universität Berlin (Peter Szondi-Institut für AVL) com bolsa FAPESP (processo 2018/19708-7). Atualmente é pós-doutorando no Departamento de Filosofia da Universidade de São Paulo (FFLCH-USP), com pesquisa supervisionada pelo Prof. Titular Marco Aurélio Werle. E-mail: <esdrasarraes@usp.br>.
\end{abstract}


and gardening in order to approaching the representation of gardens in Delille's poem "The gardens" (1782), Goethe's novel Elective affinities (1809) and in two Poe's tales - The Domain of Arnheim or The Landscape Garden (1842) and Landor's cottage. A pendant to the domain of Arnheim (1846). The narrative of text considers the two forms of eighteenth century garden - "French taste" and "landscapes-garden" - as allegories of different worldviews, which mainly concern on human being relates to its peers and with nature. The methodology employs an interdisciplinary approach with focus upon Aesthetics, Literature, Art History and Architecture.

KEYWORDS: Art. Aesthetics. Garden. Literature. Nature. Landscape. 
Historiadores da arte e arquitetos têm um papel fundamental na divulgação de questões morfológicas, historiográficas e imagéticas sobre o jardim. No entanto, atualmente há poucos registros heurísticos envolvidos em questionar as afinidades entre a literatura e a jardinagem, já que os seus vínculos epistemológicos ultrapassam propriamente os limites da forma, congregando reflexões no âmbito da estética, da antropologia e da política, além de assumirem a função de linguagem. Poemas e romances apresentam jardins, nas entrelinhas de seu discurso, não somente como cenários ficcionais ou espaços onde o homem repousa, mas sobretudo como alegorias de uma cosmovisão historicamente datada, fonte de inspiração poética e representação da subjetividade. São objetos culturais que revelam a compensação do sentimento com a geometria do traçado ou o predomínio da arte no embelezamento da natureza.

Confere-se essa hipótese quando se atém à transformação do gosto e uso do jardim em perspectiva histórica. Cabe salientar que, neste artigo, declina-se a realização de uma narrativa perfilada em sucessão cronológica da forma e função do jardim apresentadas na literatura, haja vista o trabalho hercúleo que uma proposta dessa envergadura suscita. Mas há cinco trabalhos ${ }^{3}$ dignos de menção que tomam a literatura de jardim como destinação empírica. $\bigcirc$ primeiro seria o estudo em três volumes do historiador francês Michel Baridon, ${ }^{4}$ onde o leitor percorre desde o Éden - o primeiro jardim da cultura judaico-cristã - até os grandes parques das principais metrópoles do século XX. Baridon transcreve partes de textos poéticos e tratados de jardins; elabora curtas biografias de filósofos, críticos, botânicos, arquitetos e paisagistas renomados que pensaram sobre a inserção da jardinagem na cultura, além de ilustrar o conjunto dos textos com gravuras de paisagens e jardins (des)conhecidos pelo público em geral. Sua análise histórica conjuga-se com o aspecto enciclopédico dos volumes ao elencar os agentes em diferentes temporalidades, tornando sua pesquisa completa.

Michael Gamper, ${ }^{5}$ em seu A natureza é republicana: sobre os conceitos estéticos, antropológicos e políticos da literatura de jardim alemã do século XVIII, ${ }^{6}$ se debruçou num amplo universo literário e filosófico a fim de realizar uma hermenêutica das funções estética e antropológica do jardim na sociedade alemã do Setecentos. A novidade de seu trabalho reside na exposição e identificação de um discurso republicano matizado na literatura de jardim da Alemanha pré e pósRevolução Francesa, dentre as quais se sobressaem a Teoria da arte do jardim do filósofo Christian Cay Lorenz Hirschfeld ${ }^{7}$ e o polêmico romance As afinidades eletivas de Johann Wolfgang von Goethe. ${ }^{8}$ Gamper afirma que, a partir da década de 1770, a literatura buscou revisar o posicionamento do jardim na hierarquia das artes, sendo por isso necessário reformular seu conceito que se encontrava, na crítica moderna, reduzido aos regulamentos da métrica arquitetônica. Ao invés de
3. Obviamente, existe uma miríade de pesquisas e trabalhos publicados sobre jardins. Os que estão arrolados neste artigo revelam uma escolha metodológica afinada à relação entre $\mathrm{o}$ que se convencionou chamar como Literatura de Jardim e a História da Arte. Também pode-se incluir os seguintes estudos como essenciais ao entendimento do tema: Thalmann (1949); Possin (1965); Pitte (1989); Wunderlich (1995); Segawa (1996); Porter (2004); Pinheiro; D'Agostino (2004); Vieira (2007); Wiede (2015).

4. Baridon (2018).

5. Gamper (1998).

6. Resultado de sua tese de doutorado, o título original da obra é Die Natur ist republikanisch: zu den ästhetischen, anthropologischen und politischen Konzepten der deutschen Gartenliteratur im 18. Jabrbundert.

7. Hirschfeld (1779-1785).

8. Goethe (2008a) 
9. Gamper (1998, p. 114).

10. Em inglês landscapegarden e em alemão Landschaftsgarten. Algumas traduções, em português, se referem ao neologismo como "jardim paisagístico". Prefere-se, aqui, empregar o termo jardim-paisagem, cujo conteúdo abriga a ideia de o próprio jardim ser uma paisagem.

11. Baridon (2018, p. 25).

12. Hunt (2002, p. 8).

13. Hunt (2002).

14. Beruete (2016).

15. Ibidem, p. 28.

16. Clemént (2019).

17. A ideia holística da natureza como "jardim do mundo" não é nova. Encontra-se divulgada em teorias estéticas da segunda metade do século XVIII e terá um tratamento científico aprofundado nas obras de Alexander von Humboldt, sobretudo, em Kosmos. O trabalho de Ludger Roth lança luz sobre a noção de holismo na estética do Idealismo Alemão, com ênfase na poética de Friedrich Schiller. Cf. Roth (2014). a matemática orientar o projeto, os jardins deveriam assumir a natureza como modelo de verdade, beleza e fonte de originalidade. 9 A natureza como regra estética possibilitou, na Europa, o surgimento do jardim-paisagem ou jardim paisagístico. ${ }^{10}$ Baridon prefere o designativo "jardim da sensibilidade", 11 enquanto que John Dixon Hunt, apoiado em texto de Horace Walpole, nomeia-o como "jardim pitoresco". ${ }^{12}$ Embora as terminologias sejam diferentes, elas possuem conteúdos comuns, mas sua exegese não se ajusta aos propósitos deste artigo.

As pesquisas sobre as modalidades e os dispositivos de construção de jardins na Europa do Setecentos avançaram com os textos do historiador da arte John Dixon Hunt. Especialmente em seu The picturesque Garden in Europe, ${ }^{13}$ Hunt, além de ilustrá-lo com pinturas e gravuras significativas à apreensão visual da arte, chama a atenção ao papel de poemas na compreensão de jardins e de paisagens. A obra afirma que poetas, como Delille ou William Shenstone, transcreveram o efeito pitoresco do jardim nos sentidos do homem. Por um lado, a literatura expõe as formas como o escritor pinta verbalmente seu jardim e, por outro, como o lago, a ruína, a ponte, o templo e os caminhos interferem em suas emoções.

Em Jardinosofía, Santiago Bervete ${ }^{14}$ apresenta, como Baridon, um estudo historiográfico e enciclopédico do jardim. Seu trabalho conduz o leitor, de maneira fluída e sem jargões rebuscados, a perceber a mudança de cosmovisão em momentos significativos da história, isto é, pensar a criação de jardins significa exercitar a reflexão sobre as formas como o ser humano se relaciona com a natureza em longa duração. Na mesma perspectiva de Hunt, Beruete circunscreve - jardim ao conceito de "terceira natureza". A primeira seria a natureza originária, paradisíaca, e, de certa forma, utópica. A paisagem assume a segunda natureza. Por seu turno, o jardim seria "a forma mais sofisticada de arte, uma criação artificial da modificação da paisagem pelo trabalho do homem". ${ }^{15}$

Finalmente, o paisagista francês Gilles Clément é nossa quinta referência. Seu livro - Uma breve história do jardim (Une brève histoire du jardin) ${ }^{16}$-, embora sintético, esclarece como o jardim atua na montagem da cultura. Para o autor, o primeiro jardim, sem ser o das delícias do Éden, surgiu em povos sedentários sob os imperativos da necessidade. Com muita sutileza, Clément passa de um momento histórico a outro frisando as variações sociopolíticas e estéticas impulsionadas pelos processos de criação de jardins ou da maneira como o homem assimilava a natureza envolvente. Coloca-se a pergunta: todas as sociedades constroem jardins em seus territórios? Não, se o jardim for percebido como dispositivo social que restringe a natureza em espaços ornamentados para usufruto de alguns, diz o paisagista. Em certas culturas, o planeta Terra, a natureza absoluta, seria um grande jardim, ${ }^{17}$ cabendo ao homem respeitar suas leis e preservá-la a fim de dar continuidade à vida. 
Com exceção de Gamper, cujos escritos se destinam ao entendimento da literatura de jardim e sua dimensão filosófica, os outros autores tomam a história como base teórico-metodológica. Tais estudos se ambientam num universo multidisciplinar conjugando texto e imagem como fios estruturantes de pressupostos e afirmações. De certo modo, este artigo se insere no mesmo horizonte hermenêutico, pois serão convidados à narrativa poemas, romances, teorias, histórias e pinturas. Um dos objetivos é reconhecer no discurso literário a percepção dos poetas na representação do jardim. Ou como os artistas fundamentam sua criação poética valendo-se da arquitetura do jardim. Examina-se uma temporalidade específica, entre princípios do século XVIII e as quatro primeiras décadas do século seguinte, momento no qual a articulação entre a estética nascente, o conceito filosófico de natureza, questões sociais relativas ao Antigo Regime e as alterações fisionômicas da natureza impulsionadas pela revolução industrial estavam na ordem do dia. Como este trabalho fez parte de uma pesquisa de pós-doutorado na Universidade Livre de Berlim (FUB), apresentam-se os resultados de estudos realizados com diferentes fontes documentais e a partir de visitas in situ a jardins divulgados na literatura alemã, como o Wörlitz (Figura 1), visitado oito vezes por Goethe em 1778 e localizado próximo à cidade de Dessau, no estado de Sachsen-Anhalt.

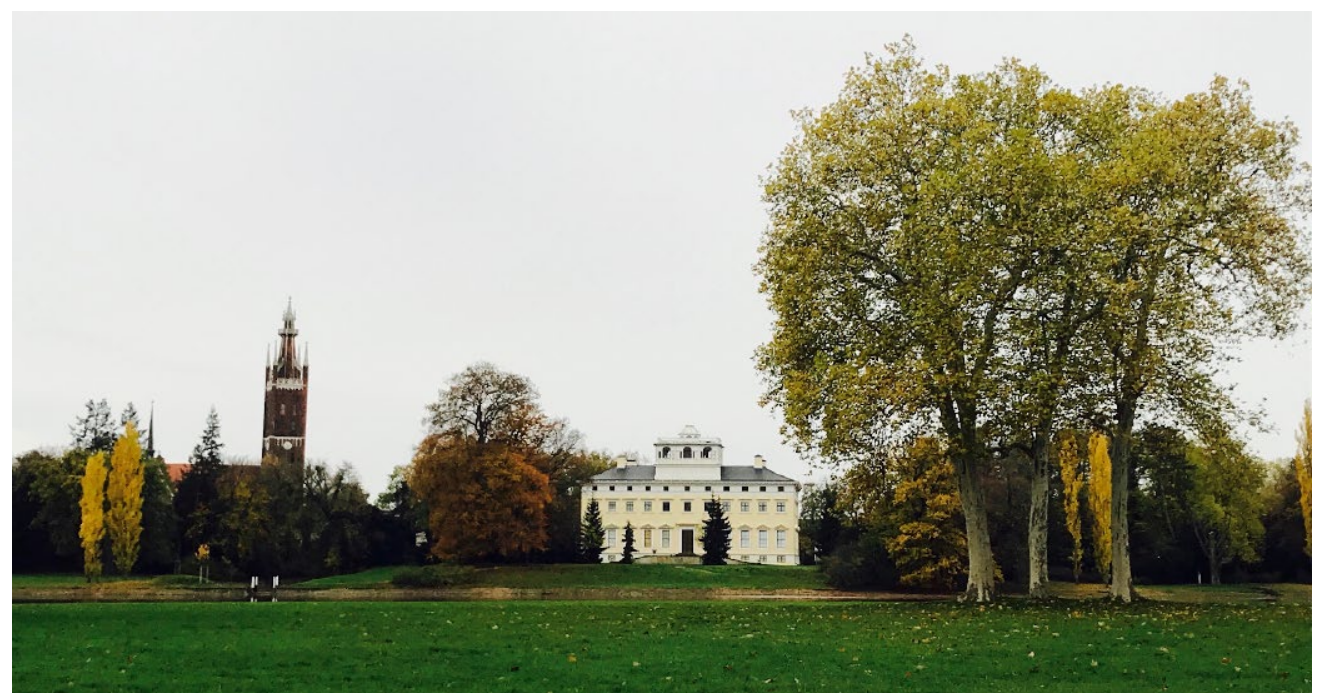

Figura 1 - Jardim Wörlitz, em Dessau (Alemanha). No centro se encontra a residência do príncipe Leopold Friedrich Franz von Anhalt. À esquerda, a igreja desenhada em estilo gótico. Foto: Esdras Araujo Arraes, 2019.

O artigo aborda quatro obras cujo conteúdo assume o jardim como tema primário ou o tem como basilar à construção poética. Inicia-se com o poema de Jacque Delille - "Os jardins" (Les jardins) - de 1782. A rápida resposta dos críticos 
18. Hirschfeld (1784, p. 1215).

19. Cf. Delille (1800).

20. Goethe (2008a, p. 166).

21. Para Georg Lukács (1968, p. 63), o Sturm und Drang dizia respeito à sublevação do sentimento e do "instinto vital" contra a tirania do entendimento apregoado pelo Iluminismo, enfatizando o gênio criador livre de preceptivas e da racionalidade catalográfica.

22. Downing (1859); Hazlitt (1903).

23. Há um artigo primoroso de Cláudia Valladão de Mattos que explora as imbricações do conceito de écfrase nas obras de Alexander von Humboldt, Goethe e as pinturas de paisagem de Jakob Philipp Hackert. Mattos (2004).

24. Ramos (2004, p. 147).

25. Cf. Bilman (2013, p. 5). ao poema se verifica em resenhas elaboradas em diferentes partes da Europa, como uma feita por Hirschfeld publicada na edição de 1784 do Calendário do jardim (Gartenkalender). ${ }^{18}$ Devido a uma escolha metodológica, emprega-se a tradução de Manoel Maria de Barbosa du Bocage de 1800.19

Segue o romance de Johann Wolfgang von Goethe - As afinidades eletivas - que veio a público em 1809, recebendo na época uma reação negativa das classes sociais mais conservadoras da Alemanha. $\bigcirc$ renomado poeta situa o jardim em dois vieses complementares. Primeiro, como exposição da subjetividade de alguns personagens e como parte de um todo perceptível na natureza, e, segundo, como objeto representativo de momentos históricos interdependentes. É no jardim, para Goethe, onde "o efêmero e o duradouro se interpenetram". ${ }^{20}$ Jardins e paisagens aparecem retratados em seus poemas e romances de juventude, quando Goethe havia aderido à estética do movimento Sturm und Drang ${ }^{21}$ (Tempestade e Ímpeto), como no Werther ou na primeira parte do Fausto.

Conclui-se com leituras de dois contos do escritor estadunidense Edgar Allan Poe - O domínio de Arnheim ou o jardim-paisagem (The Domain of Arnheim or The Landscape Garden) (1842) e A cottage de Landor. Um caminhante no domínio de Arnheim (Landor's cottage. A pendant to the domain of Arnheim) (1846) -, nos quais existe a possibilidade de inferir sobre a circulação de modelos e de conceitos sobre jardins entre a Europa e os Estados Unidos. Com efeito, Poe se inteirou da teoria da jardinagem por meio do tratado do arquiteto Andrew Jackson Downing e dos escritos de William Hazlitt. ${ }^{22}$ Qual o significado que $\mathrm{o}$ autor americano deu ao jardim vivenciado por seus personagens? $\bigcirc$ elo que une os escritos é a predominância da arte na decoração da natureza, embora a ideia do jardim-paisagem o recuse em sua teoria e projeto.

A vinculação entre texto e imagem, aqui explorada, afina-se com o conceito de écfrase (do grego ekphrasis, "descrição"), constatada nas obras de Delille, Goethe e Poe especialmente no momento em que tais autores descrevem os aspectos compositivos e pictóricos da paisagem. ${ }^{23}$ De acordo com o antropólogo português Manuel João Ramos, a palavra écfrase foi originalmente utilizada pelos retóricos da Grécia Clássica no intuito de qualificar uma descrição de grande conteúdo visual. ${ }^{24}$ Nesse sentido, poemas e pinturas servem de mediação entre a realidade objetiva e o universo subjetivo do artista e do leitor. Há um efeito da descrição da imagem nos sentidos do leitor/espectador, pois o autor, valendo-se da composição pictórica como instrumento de criação poética, confronta-se com uma realidade formada por objetos e emoções variadas. ${ }^{25}$

A literatura abordada serve como decodificadora da cultura de uma sociedade, permitindo a compreensão dos qualificativos políiticos, científicos e 
artísticos do jardim, sua utilidade e as emoções desencadeadas naqueles que o desfrutam. ${ }^{26} \bigcirc$ desenho dos dois estilos de jardim do século XVIII aparece nessas obras como motivos à criação poética, seja no âmbito laudatório ou crítico. Dessa maneira, parece oportuno diferenciá-los em termos estilísticos e historiográficos para, a seguir, considerar a imagem criada por cada escritor.

\section{O JARDIM DE GOSTO FRANCÊS E O JARDIM PAISAGÍSTICO: DESENHO E DISCURSO}

Na Europa Moderna havia dois estilos de jardins ou duas expressões sensíveis da interação do homem com a natureza. ${ }^{27} \bigcirc$ primeiro, chamado por Hirschfeld de "jardim de gosto francês", "jardim regular" ou "jardim simétrico", ${ }^{28}$ surgiu da criatividade do arquiteto contratado por reis, príncipes e nobres (Figura 2). Referia-se a uma composição submetida à norma da geometria, orientando-se por figuras regulares. $\bigcirc$ arquiteto recorria à perspectiva, situando em pontos de fuga o castelo, obeliscos, as fontes e as esculturas no intuito de manipular ou conduzir o olhar do visitante a tais objetos. $\bigcirc$ castelo ou residência principal, geralmente posicionado na entrada do jardim, possibilitou a formulação de um grande eixo central de simetria.

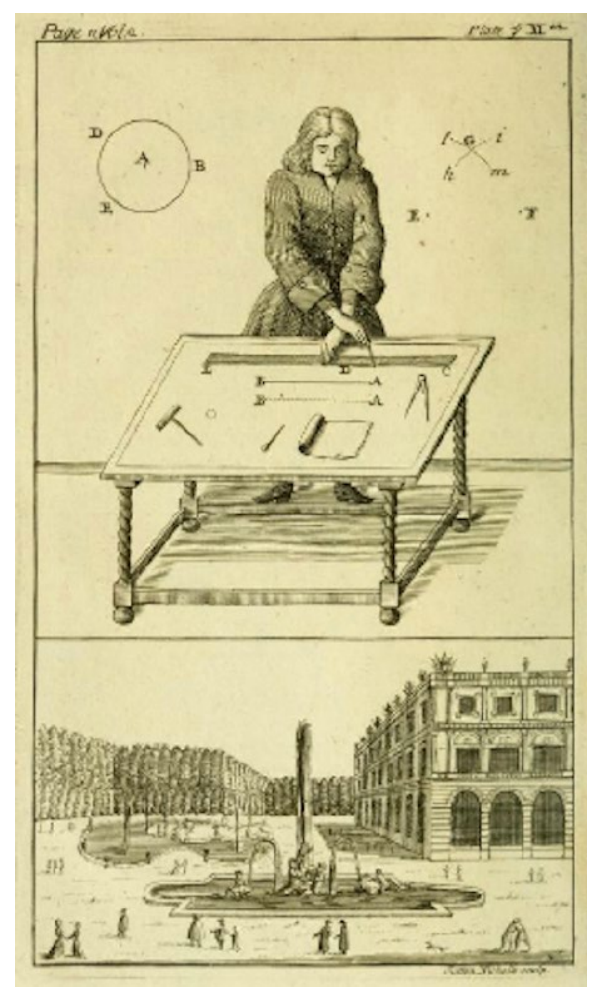

26. Cf. Arraes (2019, p. 4770).

27. Sobre a relação entre homem e natureza no Setecentos, sugere-se a leitura de Keith (2010) e Oelschlaeger (1991).

28. Hirschfeld (1. v., 1779, p. 117). Adota-se nos parágrafos seguintes as três denominações como sinônimos e para não sobrecarregar $o$ texto com um único termo.

Figura 2 - Ofício do arquiteto de jardins. Fonte: Switzer (1718, p. 11). 
29. Fariello (2008, p. 125).

30. Wiede (2015, p. 33).

31. Fariello (2008, p. 126).

32. Apud Wiede (2015, p. 45).

33. Cf. Arraes (2017, p. 3757).

34. Campbell (1725).
O jardim simétrico deu continuidade às preceptivas estéticas do Renascimento italiano. De acordo com Francesco Fariello, os jardins das vilas italianas serviram de modelo na França, tanto para a aceitação de ideias como para a maneira de projetar os espaços, após uma expedição do rei Carlos III à Itália realizada no final do século XV. ${ }^{29}$ Os edifícios e jardins da corte de Nápoles surpreenderam o monarca a ponto de admitir 22 artistas italianos em seu séquito de retorno à França, dentre esses os jardineiros Pacello da Mercogliano e Gerolamo da Napoli. ${ }^{30}$

Espalharam-se em seu reino jardins cujo espetáculo das formas dignificava a figura régia, como em Château-Gaillard, Gaillon e em Blois, projetados por Pacello. ${ }^{31}$

Os exemplares do século XVI e XVII se caracterizavam por conduzir o sentido da vista a apreciar uma natureza sujeita a ditames lógicos e mensuráveis. Isso é sintomático na obra do jesuíta e poeta René Rapin (1621-1687) - Hortorum libri IV - a qual incentivava a construção de jardins como cenários arranjados em desenhos estritamente regulares. Recomenda-se que árvores sejam plantadas em quadrículas circundadas por pequenos arbustos..$^{32} \mathrm{~A}$ perspectiva, como inovação da técnica do olhar, simulou a natureza em espécies de quadros organizados e coerentes, uma totalidade percebida sensivelmente. ${ }^{33} \mathrm{~A}$ excessiva ortogonalidade simboliza a sujeição da natureza aos desígnios mecânicos, quer dizer, a razão constrange a liberdade das forças da natureza livre. Era o modelo das convenções políticas do Antigo Regime afeito à conjuntura do absolutismo monárquico e ao empirismo científico. Numa concepção tal, os elementos da natureza sucumbiram ao manejo do homem e a harmonia do jardim emanava das mesmas formas disciplinares da arquitetura clássica: determinismo geométrico e matemático, abstração, perfeição, simetria, regularidade, função e utilidade.

Não foi difícil para que a nobreza de outros reinos europeus adotasse o jardim regular como símbolo de gosto e de posicionamento social. $\bigcirc$ terceiro volume de Vitruvius Britannicus de Colen Campbell encontra-se ilustrado com imagens de jardins da Inglaterra desenhados segundo o "gosto francês", ${ }^{34}$ como o de Eastbury em Dorsetshire. Nos Países Baixos apareceram exemplares que celebravam a geometria e o uso da linha reta como representação da harmonia em detrimento das linhas irregulares características da natureza. $\bigcirc$ jardim em Enghien (Figura 3), hoje situado na cidade belga homônima, expõe perfeitamente a ideia de um espaço ajardinado construído segundo ortogonalidade e simetria. A novidade desse jardim consistiu em posicionar um pavilhão (Figura 4) no eixo central, em vez de um castelo, como habitualmente se planejava. $\bigcirc$ uso da arte prevalece nesses espaços como instrumento de decoração da natureza, sem a qual tudo seria caos e desordem. 


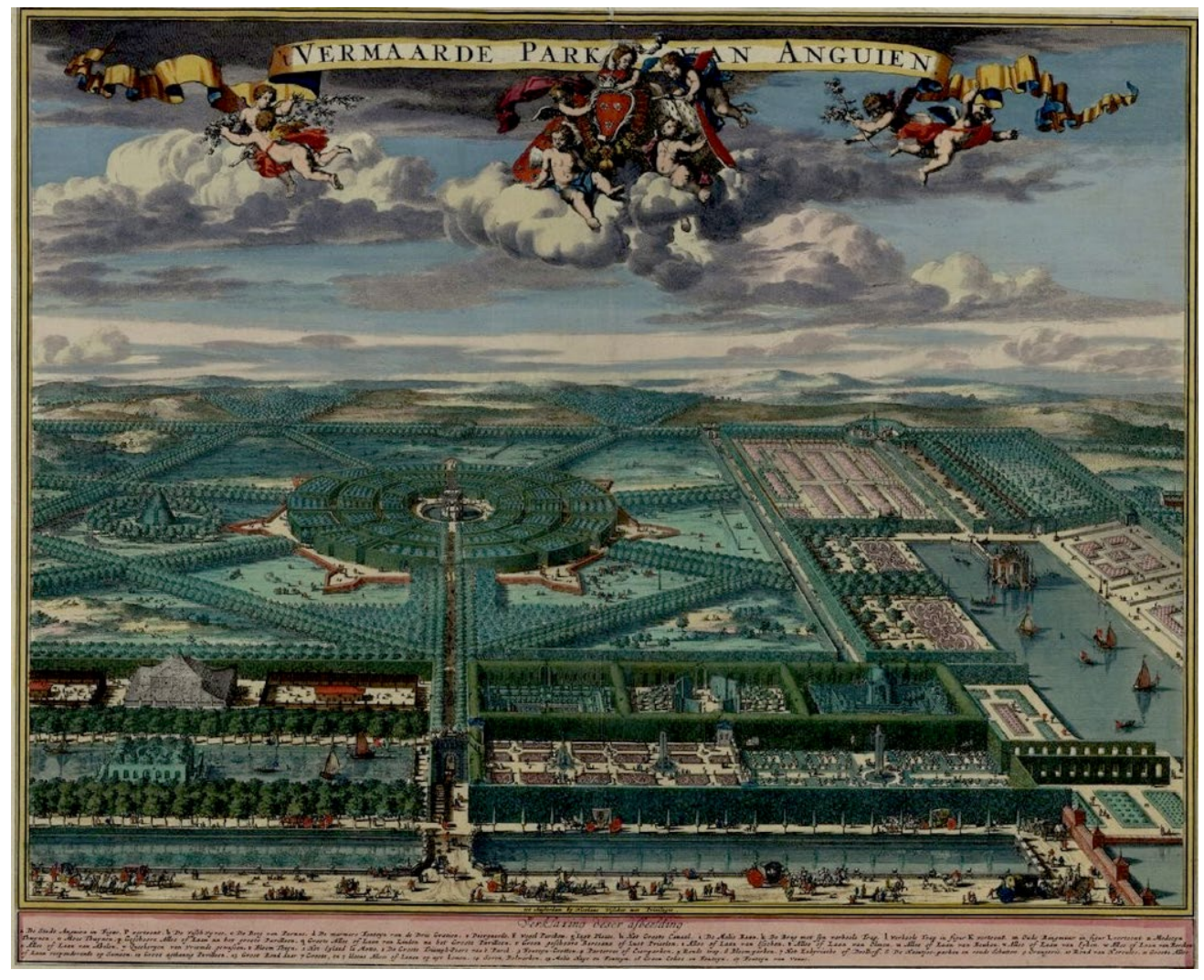

Figura 3 - Nicolaes Janz Visscher. Jardim da cidade de Enghien, Bélgica. Fonte: Gallica. Disponível em: <https://bit. ly/3nOOSSf>. Acesso em: 12 abr. 2020.

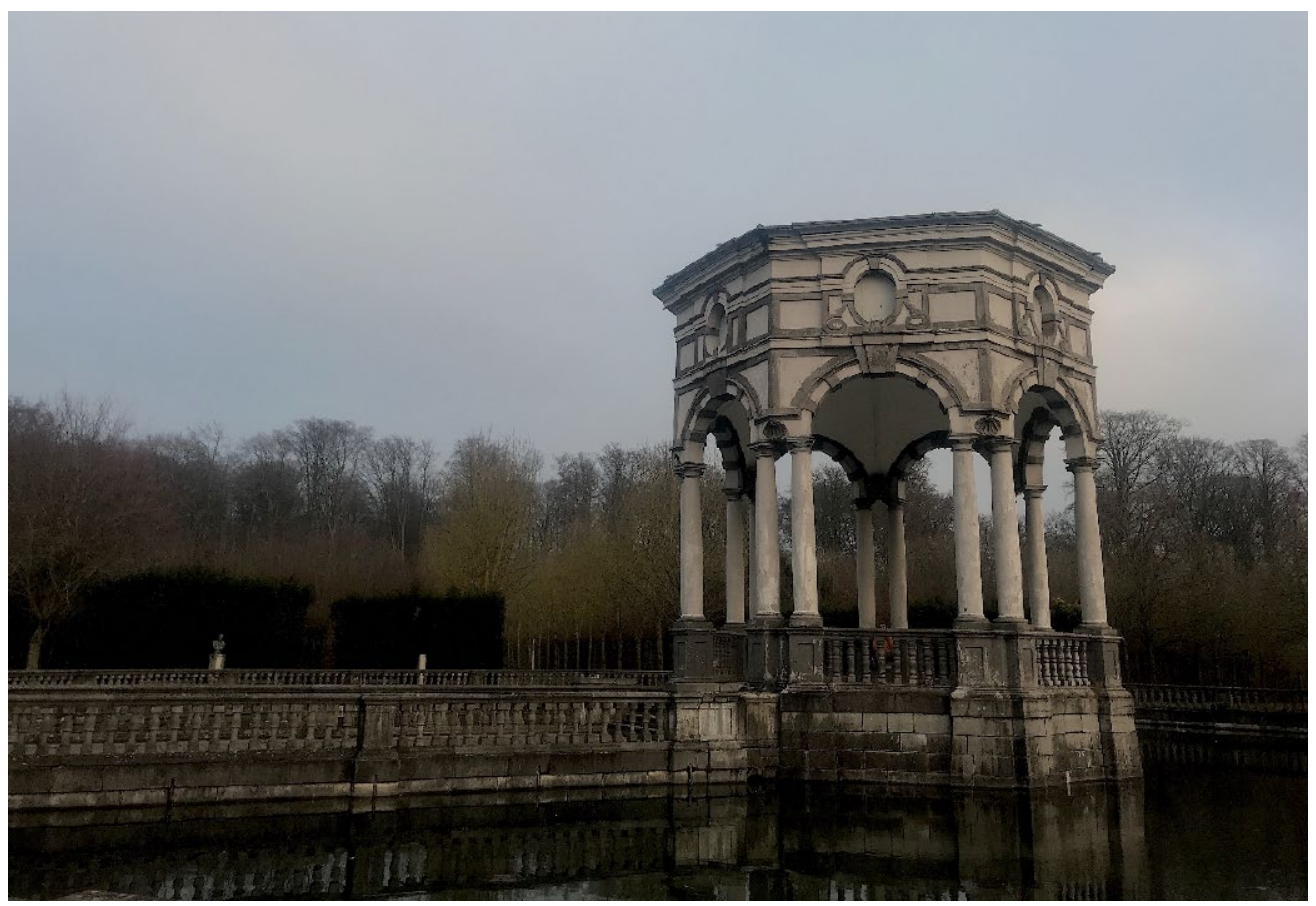

Figura 4 - Vista do pavilhão do jardim de Enghien, Bélgica. Foto: Esdras Araujo Arraes, 2020. 
35. Jeannel (2003, p. 18).

36. Fariello (2008. p. 149).

37. Cf. Bending (1994).

38. Textos sobre jardinagem foram publicados na Inglaterra no Seiscentos. O filósofo Francis Bacon escreveu, em 1625, seu "Sobre os jardins" (On gardens) com o objetivo de descrever um jardim ideal de fisionomia edênica. Há no discurso baconiano um certo mal-estar em relação ao excesso de ortogonalidade do jardim de gosto francês e à topiaria, defendendo uma composição alinhada às formas da natureza. Bacon (1908).
Mas o emblema representativo do jardim de gosto francês e do absolutismo monárquico é, sem dúvida, Versailles, projeto de André Le Nôtre, arquiteto da corte de Luís XIV. Nos jardins de Le Nôtre ordem e proporção contribuem à eloquência do desenho. Prolongando a cadência dos elementos da composição - alamedas, terraços, labirintos, topiaria etc. - para a arquitetura que o circunda, o jardim expressa suas leis numa visão científica a partir da oposição de sua aparência regular com os contornos irregulares da natureza. ${ }^{35}$ Versailles assume idealmente a subordinação da natureza ao cânone da abstração matemática. Le Nôtre havia viajado para a Itália, com o apoio financeiro da Academia Real de Arquitetura (fundada em 1671), antes de empreender as obras do jardim da residência régia. Seu conhecimento científico gravitava em torno da óptica, geometria e topografia, disciplinas cuja epistemologia concebe o entendimento dos fenômenos naturais via pragmatismo. As amplas perspectivas e o parterre de Versailles, seus labirintos e alamedas resultaram de exercícios operados na prancheta e na mensuração do terreno feitos com o auxílio de instrumentos geodésicos ou mesmo da tesoura do jardineiro. Toda a ornamentação se fundamenta no simbolismo preciso celebrado no mito de Apolo, o deus sol, assumido como a própria imagem de Luís XIV, o rei sol. ${ }^{36}$

No entanto, uma nova compreensão da natureza começou a se instaurar na Europa em princípios do Setecentos. Uma mirada mais sensível e menos mecanicista do mundo inspirou pintores, filósofos, poetas e mesmo arquitetos a evocarem a natureza originária, simples e divina, arquétipo de todas as artes e das relações éticas e morais firmadas em sociedade. Esse novo direcionamento implicou a transição histórica não somente do emblema para a metáfora, da empiria à emoção, mas do artificial ao cada vez mais natural. ${ }^{37} \mathrm{O}$ jardim regular amortece esses qualificativos em formas construídas pelo artifício humano. Inclusive frustra a natureza de seguir a liberdade de suas leis exposta na objetividade de sua apresentação (natura naturata) e nos fenômenos velados aos sentidos humanos (natura naturans). Sem demora surgiram críticas, tratados e estudos contra a regularidade do jardim como símbolo de uma Coroa ou nobreza vinculada aos velhos costumes feudais. São escritos que, em certo nível, invalidam o trabalho do arquiteto sujeito à decoração geométrica, para dar voz às composições poéticas, à pintura de paisagem e às reflexões filosóficas.

A Inglaterra protagonizou na Europa o ponto de inflexão, 38 fornecendo às outras partes do continente as bases estéticas e ideológicas, particularmente depois dos eventos ocorridos na Revolução Gloriosa de 1688, que culminaram na fuga do rei católico James $I I$ e no coroamento de seu cunhado protestante, William III. Conforme Baridon, a revolução de 1688 pôs fim ao direito divino dos reis que os Stuarts tentaram implementar segundo o modelo absolutista 
francês. ${ }^{39}$ De fato, as disputas políticas lideradas no parlamento pelos Tories, mais liberais, visavam a cercear o poder da dinastia dos Stuarts.

Muitos dos pintores, poetas e críticos, admiradores do jardim-paisagem, simpatizavam com os Tories ou eram associados ao partido. ${ }^{40}$ Os textos de Joseph Addison, Alexander Pope, William Temple e Horace Walpole, ${ }^{41}$ publicados desde a década de 1710 nos jornais The Spectator e The Guardian, são indispensáveis ao entendimento da crítica destinada ao jardim simétrico e, de reboque, às categorias subsumidas no universo da arquitetura. Na edição de 25 de junho de 1713 do The Spectator, Addison manifesta sua preferência pela arte que possibilite à natureza se desenvolver livremente em consonância com sua própria inclinação vital, sem frear a espontaneidade de seus elementos constitutivos em topiarias ou cenários desenhados sob a égide do luxo. ${ }^{42}$

$\bigcirc$ topos poético da narrativa desses escritos consiste em admitir o mito edênico como modelo de representação paisagística. No Éden, os primeiros humanos desfrutavam dos prazeres da natureza inconscientes da inexorabilidade do tempo e das exigências culturais. Sua condição de inocência se afeiçoava à natureza original, perfeita e variada, assim como à solidão e à irregularidade da forma. Em termos políticos e morais, o jardim primordial seria idealmente a própria Inglaterra, julgada por seus poetas como o reino da restauração e da liberdade dos povos. $\bigcirc$ liberalismo econômico teorizado por John Locke e Adam Smith influenciou artistas e jardineiros a substituir o cânone da arquitetura por uma composição orientada pela ideia de imitatio naturae. ${ }^{43}$

Outras críticas surgiram na Alemanha e na França sobretudo a partir da segunda metade do século XVIII. Hirschfeld foi de fato o comentador mais loquaz contrário à estética do jardim francês. Chegou a afirmar que a proporção regular se alia à forma pouco natural da topiaria (para ele uma sociedade de bonecos), cuja bizarrice exaure a verdadeira exposição do belo natural apresentado na desordem de sua aparência. A exegese do autor da Teoria da arte do jardim reivindicou a liberdade do homem identificada na livre formação da natureza, ao invés de constrangê-la em cenários espetaculares projetados para honrar a monarquia e a frivolidade da nobreza. Nesse aspecto, Hirschfeld propõe o retorno do homem ao campo, onde a sensibilidade se compensa com paisagens bucólicas. ${ }^{44}$ Seria nessa utópica arcádia onde ocorreria a depuração moral perdida na cidade. A Inglaterra forneceu os princípios políticos e econômicos da liberdade, mas a Suíça seria o símbolo da paisagem ideal convertida ela mesma em jardim: "O amigo da vida no campo encontrará aqui [Suíça] distintos prazeres, uma quantidade de vistas mágicas convertidas em seu jardim". ${ }^{45}$
39. Baridon (2018, p. 13).

40. Trotha (1999, p. 12).

41. Cf. Salván (2006).

42. Cf. Assunto (1991, p. 76).

43. Cf. Hermand (1997).

44. Para o aprofundamento da imbricação entre vida no campo e restauração moral na literatura do século XVIII, cf. Hirschfeld (1776).

45. Hirschfeld (1. v., 1779, p. 34). 
interesse pela concepção do jardim-paisagem cresceu também na França. $\bigcirc$ jardim de René-Lovis de Girardin, em Ermenonville, é um exemplo do afastamento da ortogonalidade (Figura 5). Com seus pequenos promontórios, vales, bosques, lagos, pântanos e córregos, aquele lugar oferecia ao visitante o todo do espetáculo da natureza. Jean-Jacques Rousseau vivenciou-o, a convite do proprietário, antes de escrever Julie ou mesmo sobre o lugar - social e político - do homem na natureza. $\bigcirc$ filósofo francês pregou a legitimação do movimento da razão à subjetividade, situando a transparência das emoções no centro da vida humana em vez do intelecto, a consciência de uma força divina que habita a natureza no lugar da ciência. ${ }^{46}$

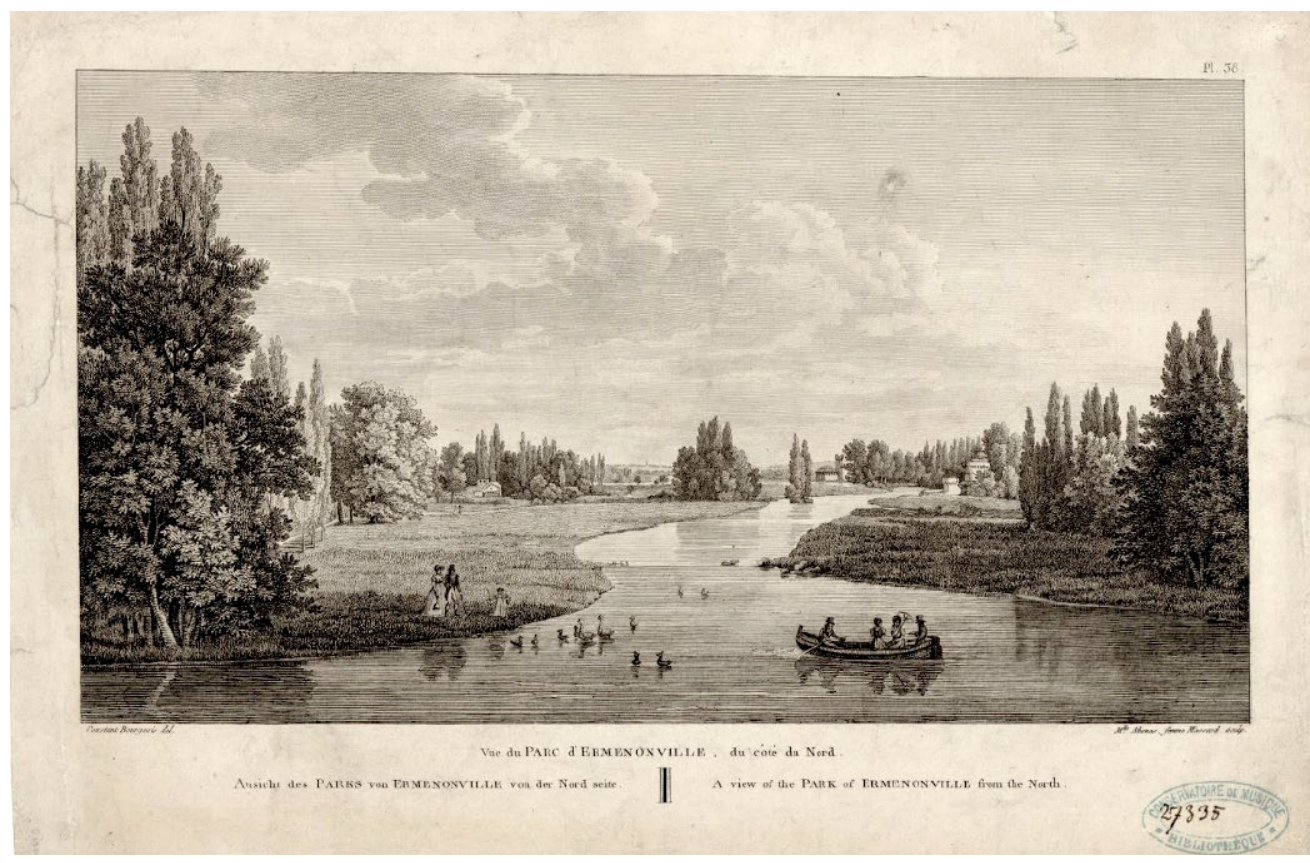

Figura 5 - Vista do jardim de Ermenonville, autoria de Constant Bourgeois, 1808. Fonte: Gallica. Disponivel em: <https://bit.ly/3nOOSSf>. Acesso em: 12 abr. 2020.

Em Julie ou A nova Heloísa (1761), Rousseau expõe um jardim no qual a natureza predomina sobre a razão. Para Clément, o filósofo francês considerou o sequenciamento da natureza na arte não somente como uma revisão estética, mas sobretudo como axioma da autonomia da subjetividade humana. ${ }^{47}$ A obra conta sobre um lugar nunca antes visitado e chamado, por Julie, de Elisium. Elisium imitou o solo imaculado antes do pecado original, a utopia para qual o ser retorna depois da corrupção da cultura, o mundo que exala a fantasia da natureza prístina.

Saint Preux - um jovem viajante que havia regressado de uma expedição ao Pacífico e apaixonado por Julie - afirmou no momento que adentrou nos 
segredos do jardim: "mesmo que o nome Elisium evoque a ordem das aberrações da imaginação, trouxe à minha alma a calma das agitações da paixão". ${ }^{48}$ Havia a necessidade de reivindicar o estilo de vida da ldade do Ouro, na qual o homem encontra sua felicidade equilibrando os sentimentos com a natureza envolvente. $\bigcirc$ Elisium seria um "jardim das árvores", formalmente inspirado na natureza originária. Dessa maneira, o uso da topiaria e de esculturas moldadas em ferro corrompiam a eternidade da natureza, além de refletirem as vaidades do proprietário.

Paradoxalmente, se o prístino era o efeito desejado, deveria ser cultivado, e, portanto, objeto da cultura. Em outras palavras, o jardim seria uma criação da subjetividade com o apoio do trabalho do jardineiro. A observação de Julie ao seu Elisium é, nesse caso, sugestiva: "é verdade [...] que a natureza fez tudo, mas sob minha direção não há nada aqui que eu não tenha projetado". ${ }^{49}$ Embora Rousseau tenha recusado qualquer artificialidade para comunicar a natureza, ele sabia que não havia jardins sem a execução humana, mas que deveria ser ocultada das vistas do espectador: "eu não vi nenhuma pegada humana", replicou Saint Preux, pelo qual o senhor de Wolmar advertiu, "isto se dá porque nós temos o cuidado de apagá-las [...] Temos feno semeado por todos os lados e a grama logo esconde os vestígios do trabalho. Quanto ao musgo que cobre os caminhos, foi o senhor Edward quem nos enviou da Inglaterra os segredos de cultivá-lo". ${ }^{50}$

Em contraposição à abstração do jardim regular, o projeto de jardins-paisagem regulava-se pelos códigos intrínsecos à natureza. A forma reitera a nova aspiração do mundo sensível e panteísta concebida na reconciliação do homem com a natureza agora considerada divina. Esse estilo teve, para o percepcionar e o sentir, a função de tornar presente a bondade da natureza e a abundante reserva de que esta dispõe para a bem-aventurança humana, induzindo o espírito à reflexão e à contemplação. Seria o símbolo da liberdade, onde o artifício não deve prevalecer a fim de favorecer a imagem da livre natureza que acolhe a história, a cultura. ${ }^{51}$ As fontes de água com seus seres míticos foram substituídas por lagos situados em lugares propícios ao repouso. A experiência da visão se desata do ponto de fuga da perspectiva, alcançando a variedade de objetos apreendidos em caminhos sinuosos. A visão perde sua posição de sentido supremo, dando lugar a experiências sensoriais múltiplas derivadas do movimento. Privilegia-se o contato com a paisagem, aliás, o jardim seria paisagem, daí o seu designativo. Dilui-se o contraste entre ambas as categorias, antes consideradas quase como uma antítese entre o formalizado e o não formalizado. ${ }^{52}$

Para a maioria dos escritores ingleses, alemães e franceses contrários ao Antigo Regime, a linha reta havia se tornado o signo de uma monarquia talhada por cosmovisões da ldade Média incongruente com os valores modernos de liberdade e autonomia. A serpentina e outras estruturas assimétricas denotavam tais condições,
48. Rousseau (1997, p. 400).

49. Ibidem, p. 388 .

50. Ibid., p. 393.

51. Fariello (2008, p. 132).

52. Hunt (2002, p. 30). 
53. Baridon (2018, p. 24).

54. Girardin (1777, p. 7).

55. Cf. Niedermeier (1994). seja na dimensão política ou no aspecto religioso. Baridon frisa o conflito de ideologias entre os atores situados nos dois polos. Enquanto um Walpole se serviu do contraste das assimetrias para manifestar seus posicionamentos estéticos e políticos, André Mollet, defensor da Coroa francesa, enfatizou o círculo e o retângulo como figuras essencialmente belas, inclusive por serem idiossincráticas à natureza. ${ }^{53}$

Nessa arena de embates transparecia o julgamento da práxis do arquiteto criador de jardins regulares e a valorização do jardim-paisagem como o espaço no qual pintores e poetas experimentavam a simplicidade e a graça de seu ofício. Não por acaso que René-Louis de Girardin, em seu tratado sobre a composição de jardins e paisagens, valida a pintura e a poesia como as artes que representam os "belos efeitos da natureza". ${ }^{54}$ Delille, Goethe e Poe declararam, cada um a seu modo, afinidade ou negação à estética das duas modalidades em questão. Em "Os jardins", o poeta francês teceu elogios à jardinagem assimétrica, enquanto o autor de As afinidades eletivas criticou ambos os estilos. A análise goethiana ancora-se numa perspectiva schilleriana, compreendendo o jardim como a síntese da natureza e da sensibilidade. Poe de certa forma concordou com Goethe e Delille, percebendo a ocultação da arte na mimese da natureza e a irregularidade como aparência do belo.

\section{OS JARDINS DE DELILLE}

Jacques Delille nasceu, em 1738, em uma pequena cidade situada na região francesa de Auvergne. Ainda jovem foi enviado a Paris para concluir seus estudos no Collége Libieux. Na década de 1770, ingressou na Academia Francesa após traduzir as Geórgicas de Virgílio. No ano efervescente de 1789, decidiu se mudar da capital, estabelecendo-se, inicialmente, em Saint Diez para, em seguida, viver por um longo período em Basel. De volta à Paris, em princípios do século XIX, traduziu para o francês a Eneida de Virgílio (1804), o Paraíso perdido de John Milton (1805) e, em 1809, publicou Os três reinos da natureza (Le trois règnes de la natur). Em 1813, o poeta-tradutor faleceu em Paris. ${ }^{55} \mathrm{O}$ poema "Os jardins" representa um dos marcos literários da introdução do gosto do jardim-paisagem no cenário cultural da França pré-revolucionária.

"Os jardins" se divide em quatro cantos compostos, sobretudo, por alexandrinos. O didatismo da obra, criticado por seu tradutor português, Du Bocage, aproxima o leitor dos debates em torno dos estilos coevos, tornando compreensível um léxico próprio de arquitetos, pintores, filósofos e poetas. Essa característica aparece também na escolha de perfilar a composição poética em perspectiva histórica, arrolando 
exemplos conhecidos, como o Éden l"origem teve nos cerúleos dias, nas primaveras do recente Globo"), ${ }^{56}$ os jardins suspensos da antiga Babilônia, o de Alcinoo descrito na Odisseia de Homero, os Campos Elísios dos gregos e o Hortus Conclusus da ldade Média. Durante a leitura dos versos, é notório o posicionamento da sensibilidade do poeta ou do pintor acima da do arquiteto, aquele que "desnaturaliza e perde tudo". ${ }^{57}$

No primeiro canto detecta-se a preferência de Delille pelo então chamado jardim-paisagem. Seu julgamento negativo se destina à modalidade que insulta "co'a pompa a natureza", 58 pois o jardim, a arte de decorar os terrenos, deve imitar as leis que regem a natureza, apresentando-as como uma sucessão de quadros distintos. Nesse aspecto, o jardim que, aceita como exemplar o fenômeno da natureza, desligase da esfera da arquitetura, assumindo a pintura de paisagem como destino de criação estética: "De compasso na destra, embora ordene/ Artífice vulgar a symmetria/ D'enfadoso jardim, confie embora/ o Geométrico plano ao papel frio" ${ }^{59} \mathrm{O}$ olhar pictórico do artista transmite para a tela a vida da natureza, isto é, o colorido, a luz, a sombra, o movimento e os efeitos provocados no espírito, se sublimes ou pincelados com graça. A paisagem representada em quadro seria a metáfora do jardim, e este seria a própria paisagem. A pintura de paisagem expunha o genius loci, ou espírito do lugar, comprometendo-se em figurar uma natureza idealizada.

Mas dentro dessa leitura reside a noção, comum no Setecentos, de que a poesia compõe verdadeiras pinturas em seus versos. Não é inocente o imperativo do poeta: "Parece aos olhos hum amplo quadro./ Sede pintor: o campo, os seus matizes, / os reflexos da luz, da sombra as massas, / As estações, e as horas, variando/ o giro do anno, o círculo diurno". 60 Tais pinturas textuais evocam paisagens de Poussin, de Berghe e de outros pintores que restituíram à natureza suas características perdidas na ratio cartesiana ou submetidas aos experimentos laboratoriais. A aspiração de Delille de situar em paridade jardim e pintura equivale, como os artistas e críticos ingleses fizeram em sua ilha, a restabelecer utopicamente na França o paraíso obliterado pela monarquia e seus vícios morais: "A casa Patria minha se transforme/ Toda em vasto jardim, n'um Eden Novo!". 61

O aspecto pedagógico do poema reaparece no final do primeiro canto, quando se procura configurar a estética dos dois estilos de jardinagem. $\bigcirc$ jardim regular reproduz a "ordem grave" dando freio às árvores em sua "verde arquitetura". É a imagem negativa do "déspota orgulhoso" que atrofia o riso e a graça. Em compensação, o amante da natureza extrai a arte da irregularidade, convertendo em beleza o "desleixo", a "desordem" e o "acaso".62 Para Delille, as "gratas desordens" da natureza afetam a emoção do espectador porque o entretém na variedade. As diversas paisagens enquadradas pela visão produziam um efeito positivo na imaginação, de amplitude e de liberdade. Cada gênero tem seu representante: Le
56. Delille (1800, p. 5)

57. Ibidem, p. 11.

58. Ibid., p. 9.

59. Ibid., p.13

60. Ibid., p. 7, grifo nosso.

61. Ibid., p. 25 .

62. Ibid., p. 29 
63. Apud Trotha (1999, p. 31).

64. Baridon (2018, p. 32).

65. Delille (1800, p. 47).

66. Ibidem, p. 45.

67. Ibid., p. 55.

68. Ibid., p. 57.
Nôtre criou para "Grandes, e Reis"; William Kent, arquiteto e artista inglês, preferiu a serpentina em oposição à linha reta. Kent foi o primeiro criador, na Inglaterra, de espaços ajardinados com formas emprestadas da natureza. Logo apareceram seus admiradores, como Walpole, que o nomeou de "pai da moderna jardinagem".63

poema descreve $\circ$ jardim de gosto francês numa chave negativa. $\bigcirc$ poeta assimila desordem e irregularidade como categorias positivas justamente por sua naturalidade. O que prevalece no aparente desarranjo é a apreensão do conjunto que, constituído de diversidade, transforma-se num todo harmonioso. $O$ efeito que a harmonia do jardim-paisagem suscita no observador é um dos temas do segundo canto, se não o predominante.

Esse efeito é em geral assimilado no âmbito subjetivo. Busca-se mostrar que o jardim e suas partes formativas provocam determinadas reações na alma do sujeito. Por isso a subjetividade é significativa na representação dos jardins, sendo comum nos textos que os descrevem aparecerem termos como "sensação", "sentimento", "sem sabor", entre outros. ${ }^{64}$ Como Delille considera a paisagem circunscrita à dimensão pictórica, o jardim-paisagem-pintura desenvolve no espírito humano sentimentos de acordo com a imagem contemplada. De fato, os efeitos negativos do jardim regular são tristeza, infortúnio, monotonia e aflição. Não há expectativa de mudança paisagística nos labirintos, nas grandes alamedas e nas árvores e arbustos podados simetricamente: "Triste esquadro, e cordel fastidioso / / [...] He a uniformidade ingrata aos olhos; / Da que vem nos jardins eles se enfadão". ${ }^{55}$ Contudo, o contraste e a rusticidade da natureza, qualificativos admitidos como nobres, além de depurarem a alma e a visão, criam paisagens sentidas como loci amoena, onde o espectador se perde em "êxtase suave, em ócio puro" ditados pelo "prazer das lições de Epicuro". ${ }^{60}$ Nos jardins onde prevalece a harmonia do todo, o homem desfruta dos "Effeitos ora doces, ora fortes, / Grandes contrastes, ou gentis concórdias".67

O tempo e sua percepção fornecem dados empíricos e subjetivos para a composição pictórica de paisagens e encontram no jardim o lugar de sua exposição ("assim com ele [ano] o teu jardim varia"). ${ }^{68}$ Intermediada pelas ruínas e estações do ano, a apreensão sensível do tempo exerce múltiplos efeitos no espírito de quem o observa. Paradoxalmente, Delille canta duas situações típicas do outono que, embora dessemelhantes, são complementares entre si. Na primeira, o jardim ostenta riqueza num colorido forjado com o amarelo dourado, o alaranjado, o vermelho e o verde resistente. Essa estação vaticina a ruína identificada no cair das folhas e na morte temporária de árvores que transcorrerá no inverno. O poeta francês celebra a gratidão da ruína do jardim outonal como condição da existência humana, isto é, como metáfora do devir histórico que transcorre entre a vida e a morte. Ironiza-se qualquer recurso que oculte o efeito do tempo. Nisso os jardins da França são exemplares: "Mas os jardins 
dos reis com que artifício,/ com que apparato esplêndido triunfão/ dos sanhudos invernos! Sempre verdes,/ Oh Moceaux! Teus jardins são disto exemplos". 69

A história do jardim de Delille narra uma cronologia de longa duração. A gruta, outro arquétipo da nobreza rústica da natureza, representa a idade geológica da Terra por antonomásia: "Vossas grutas ainda em versos instruem./ Ermos antigos, majestosas sombras". ${ }^{70}$ A visível antiguidade da gruta remete a consciência a um passado "selvagem", 71 no qual o homem se relaciona livre com a natureza, em seu estado de pureza e ingenuidade. Clemént chama a atenção para esse atributo, mostrando que cavernas e grutas acompanharam a criação de jardins em diferentes momentos da história. ${ }^{72}$ Elas formam um pathos ornamental símbolo da natureza prístina ou "mãe universal (do) benigno influxo". ${ }^{73}$

A crítica a outros objetos do jardim simétrico reaparece no terceiro canto. $\bigcirc$ parterre torna-se "Infecundo areal, e secco, e triste, / [...] importunava os pés, cansava os olhos". ${ }^{74}$ A artificialidade do parterre se contrapõe à naturalidade das relvas, dos musgos, dos bosques e do pasto introduzidos nos jardins da Inglaterra. Até o terceiro canto estava subentendida a homenagem à maneira de como os ingleses criavam seus jardins, aqui sua exposição é categórica e referencial às paisagens bucólicas recriadas nos lugares que aspiram a transmudar-se em paraísos modernos: "Do resto se componhão ricos pastos, / E somente os cultivem teus rebanhos". 75 Delille pensa nos pintores de paisagem do século XVII, ou mesmo em seus contemporâneos, no momento da escrita desses versos. Sabe-se que cenas bucólicas são temas recorrentes nos quadros de Claude Lorrain, Nicolas Poussin e Jakob Philipp Hackert.

Além dos pintores de paisagem, poetas da antiguidade e modernos buscaram traduzir em palavras a beleza pictórica e espetacular da natureza. Longe de instaurar a monotonia da "presunçosa rival da natureza larquitetura? jardim de gosto francês?)", 76 Delille salienta novamente os nexos afins entre a sensibilidade poética e a forma do jardim-paisagem. $\bigcirc$ poema foi escrito com uma série de écfrases pródigas em criar uma imagem idealizada da natureza. A écfrase conduz a imaginação do poeta a fabular versos que, como pinturas, são os meios estéticos de ornamentação da natureza. De maneira que o verde dos vergéis descritos por Virgílio mostra aos olhos do leitor a fertilidade e a beleza simples da natureza.

Dois outros nomes referenciais da crítica, literatura e técnica da jardinagem dos Setecentos são mencionados no terceiro canto: o inglês Thomas Whately e o compatriota Claude-Henri Watelet. A indicação não foi gratuita. Eles estiveram engajados em difundir o gosto do jardim-paisagem não apenas como inovação artística, mas sobretudo como alegoria do livre pensamento.
69. Ibid., p. 59.

70. Ibid., p. 43

71. Delille escreve o adjetivo "selvagem", em diferentes estrofes dos quatros cantos, segundo o entendimento rousseauniano, pelo qual o espetáculo da natureza se torna vívido no homem mediante a combinação da virtude humana com a transparência intrínseca à natureza.

72. Clemént (2019, p. 57).

73. Delille (1800, p. 19).

74. Ibidem, p. 73.

75. Ibid., p. 73.

76. Ibid., p. 79. 
77. Delille, loc. cit.

78. Baridon (2018, p. 103).

79. Whately (1777, p. 1$)$

80. Hunt (2002, p. 107).

81. Fariello (2008, p. 251).

82. Watelet (1774, p. 48).

83. Os projetos de engenharia dos jardins chineses foram bem documentados no trabalho do arquiteto inglês William Chambers (1772), publicado dois anos antes do Ensaio sobre os jardins.

84. Delille (1800, p. 109).
O elogio a Whately ocorre nos versos: "Aos Campos de Midleton, às Montanhas/ De Dovedale, te acompanho os passos, / A ellas, Whateli, comtigo subo". ${ }^{77}$ Whately exerceu atividades políticas e se envolveu no debate centrado na teoria da jardinagem. ${ }^{78}$ Seu livro Observações sobre a jardinagem moderna (Observations on Modern Gardening), embora criticado por Horace Walpole por seu teor pragmático, além de considerar a arte como mais elevada que a natureza - pois esta necessita de reparos para corrigir suas faltas e melhorar sua beleza -, ${ }^{79}$ obteve grande sucesso na Europa, sendo traduzido para o francês por François de Paule Latapie. ${ }^{80}$ Para Whately, o jardim deve se compor de quatro elementos essenciais: o terreno, as plantações de árvores, rochas e água. O significado da articulação entre essas partes formativas transcende a objetividade, estimulando a imaginação mediante o movimento ("te acompanho os passos") e uma cadeia de sensações de prazer, alegria, solidão e terror. ${ }^{81} \bigcirc$ autor de Observações discorre sobre a função do jardim nas formações estética e moral do homem. É nessa dupla atribuição que o poema de Delille relembra a figura de Whately. Mas existe outra convergência; ambos pensavam o jardim-paisagem como uma variedade de cenas formuladas nos sentidos e pensadas a partir deles.

Sem dúvida, Delille leu o Ensaio sobre os jardins (Essai sur les jardins) de Watelet (1774), uma vez que certas categorias - variedade, irregularidade, sinuosidade, assimetria, diversidade e graça - são recorrentes no poema. Ambos consideraram a simplicidade como modelo e reprovaram os códigos do Antigo Regime. O jardim de gosto francês descreve "um triste passeio [...] que deve sua origem ao orgulho feudal". ${ }^{82}$ A novidade do Ensaio decorre da sistematização dos jardins reunidos em três modalidades - o poético, o pitoresco e o romântico. $\bigcirc$ primeiro posiciona a mitologia da antiguidade como ideal de representação e procura evocar a natureza em sua totalidade. O pitoresco deve conceber paisagens e efeitos graciosos no sujeito. Oúltimo aproveita artifícios mecânicos a fim de produzir terror e maravilha. Nesse aspecto, os jardins chineses, hábeis em manejar recursos da engenharia para estimular diferentes emoções no espectador, ${ }^{83}$ foram exemplares para Watelet.

O último canto aprecia as representações poéticas do espetáculo da natureza que há nas obras de Homero e Virgílio. Está claro para Delille que o jardim dos poetas deve se apresentar à subjetividade como panegírico da natureza e de seus fenômenos visíveis. As paisagens não são uniformes, mas percebidas "em mil scenas" sucessivas, uma sendo a continuação complementar da outra - "em scenas que nascer faz outra". 84

Se nos cantos anteriores Delille não havia sido peremptório quanto à classificação dicotômica da jardinagem coeva, valendo-se de sutilezas retóricas e estéticas com o objetivo de descrever ou distinguir o jardim-paisagem do de gosto francês, ele agora revela claramente a oposição. No verso "Aos Francezes Jardins 
Britannos", acha-se uma polaridade cuja significação carrega, a título de conjectura, um discurso político travestido de sensibilidade literária. Por um lado, o poeta incentivou a introdução de jardins paisagísticos na França, que veio a se concretizar a partir da criação do jardim de Ermenonville, de Girardin e autoria do "arquiteto paisagista"85 Jean-Marie Morel. Por outro, Delille corrobora a ideia de liberdade humana e liberalismo econômico oriundos da Inglaterra e refletidos nas teorias fisiocráticas francesas.

Em seguida, o poeta compõe versos que lançam luz no jardim-paisagem como lugar de memória. Determinados objetos implantados na paisagem aparecem como epitáfios metafóricos, incentivando o usuário a relembrar o passado, a morte e aqueles que se empenharam em divulgar o novo estilo na Europa: "Não receies/ Em quadros ledos pôr sepulcros, e urnas, / Monumento fiel das magoas tuas". Há urnas no jardim de Wörlitz, como aquela que se encontra na itha de Rousseau (Figura 6); e em Ermenonville, Girardin construiu a tumba em uma ilha também consagrada ao renomado filósofo francês (Figura 7).

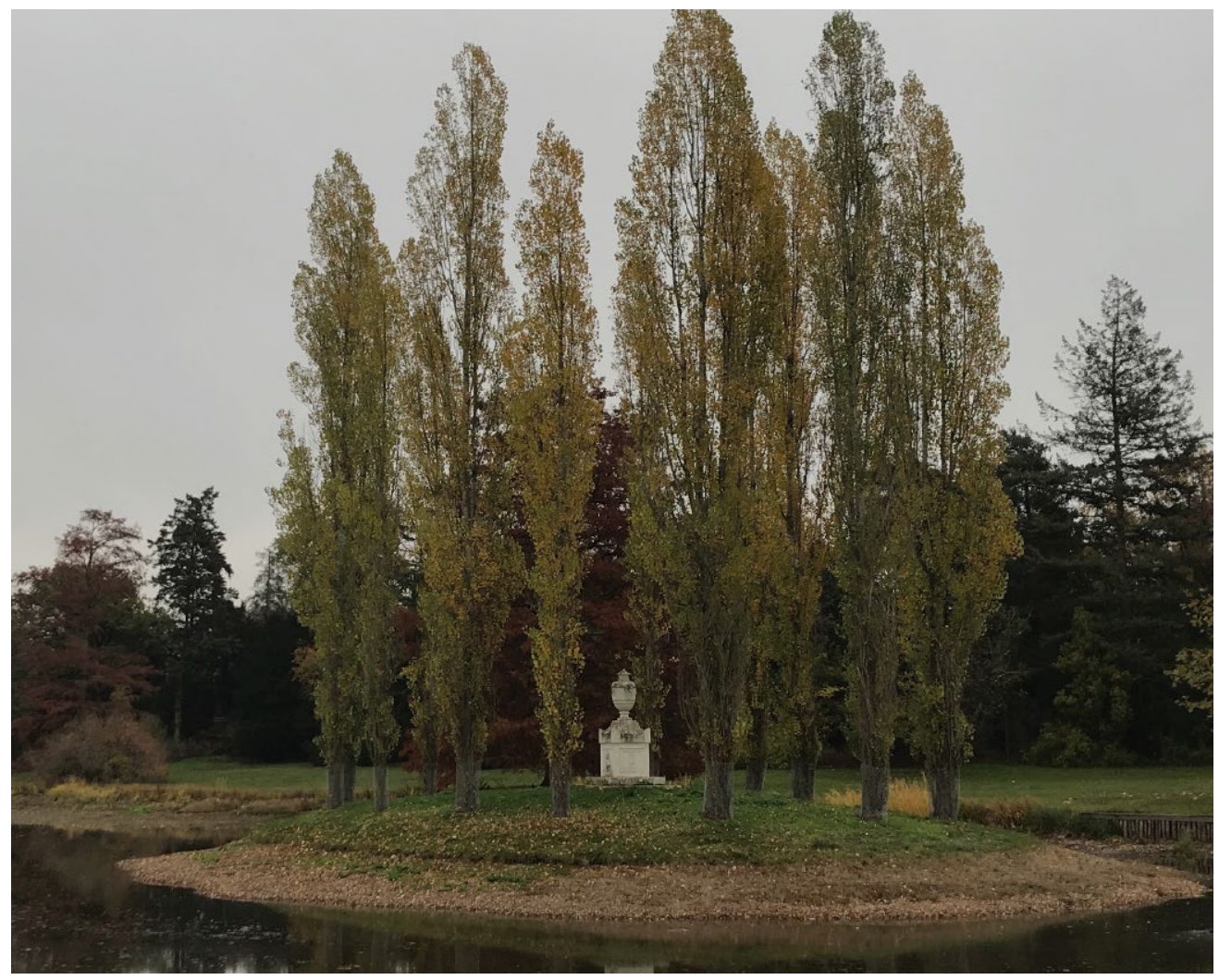

Figura 6 - Iha de Rousseau no jardim de Wörlitz. Foto: Esdras Araujo Arraes, 2019.
85. Morel pensava na insuficiência das palavras "jardineiro" e "arquiteto" para designar o artista empenhado em criar ao mesmo tempo jardim e paisagem. Por isso, ele cunhou o termo "arquiteto paisagista" na tentativa de criar um ofício tanto relativo ao domínio do arquiteto (projeto, medida, empiria) como ao do "paisagista" ou aquele que pinta paisagens (sensibilidade, subjetividade). Cf. Disponzio (2001). 
86. Delille (1800, p. 137).

87. Ibidem, p. 129.

88. Ibid., p. 69.

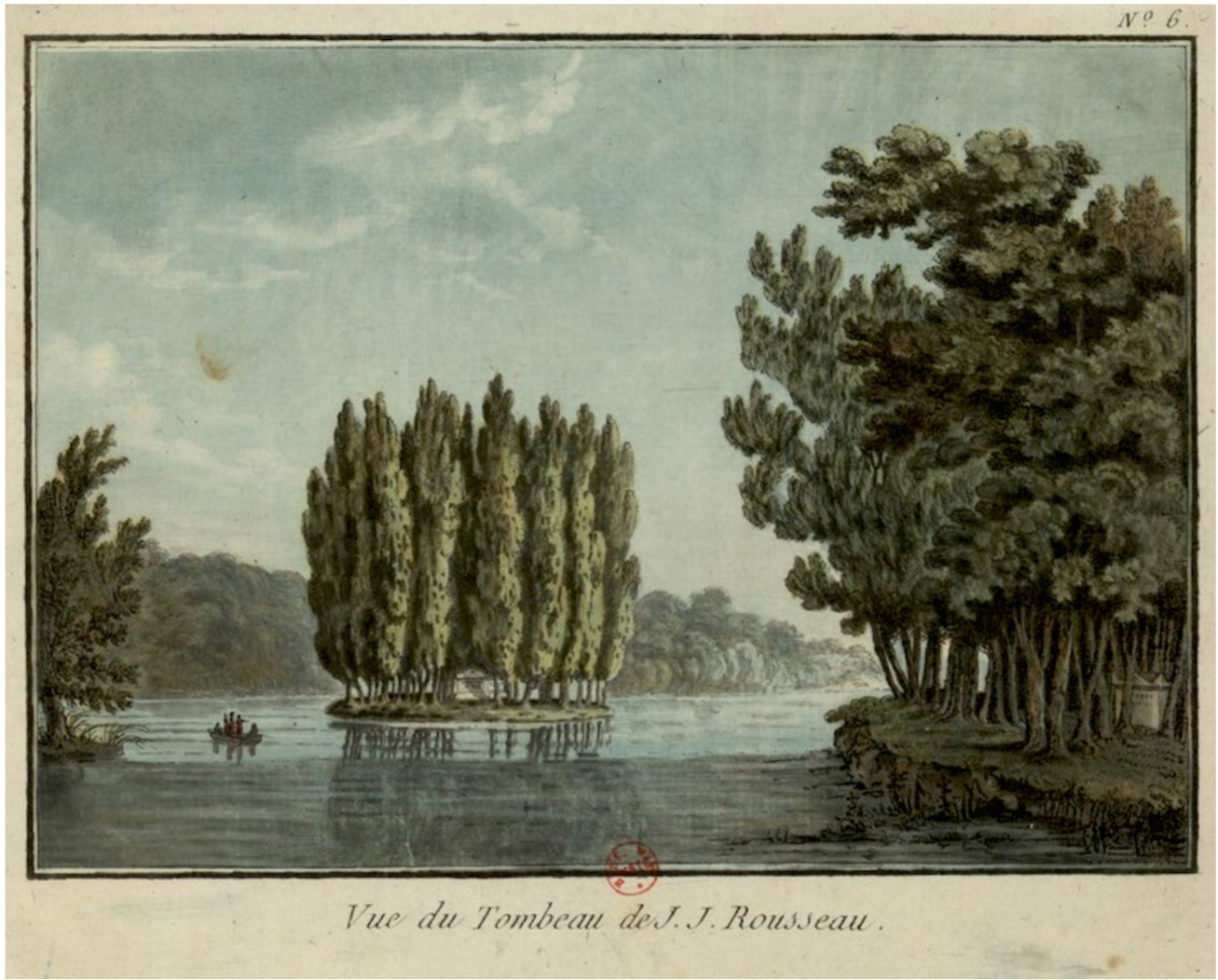

Figura 7 - Vista da ilha da tumba de Rousseau em Ermenonville, por L. Guyot. Fonte: GALLICA. Disponível em: <https://bit.ly/3nOOSSf>. Acesso em: 12 abr. 2020.

Mas é na ruína que a memória alcança maior representatividade. Ao mesmo tempo em que situa o espectador diante da história, tal objeto eterniza a antiguidade clássica e a própria poesia: "Co'a ruina immortal da excelsa Roma/ [...] Os sepulcros dos Cesares, em quanto/ De Virgilio, de Ovidio, Horacio e Outros/Inda grata ilusão nos finge o rasto./ Oh três, e quatro vezes venturoso/ O Artista dos Jardins!". ${ }^{86}$ Além de urnas e ruínas, obeliscos abrigavam a função de celebrar "nossos destemidos Mareantes, / Que pela pátria voluntários morrem". ${ }^{87}$ Delille não esquece de eventos que mudaram a cartografia do globo e a fisionomia da modernidade, por isso menciona o inglês James Cook, que havia circundado a Terra numa viagem náutica, e os campos de "O-taiti", ${ }^{88}$ referência ao trajeto marítimo de Louis-Antoine de Bougainville, que trouxe consigo, das ithas do Pacífico, árvores a serem aclimatadas nos jardins e parques franceses.

$\mathrm{Na}$ última estrofe do quarto canto, o autor introduz um argumento simultaneamente de conteúdo moral e ético cujo alcance se estenderia da Europa, origem do desenho do jardim-paisagem e seus discursos inerentes, para o restante 
da Terra. Com isso se denota a restauração, a partir do Velho Mundo, do idílio perdido em escala global, onde os diferentes povos comungariam utopicamente uma unidade cultural em felicidade plena:

Desce, Prole do Ceo, Paz suspirada,

Doira este Globo, emfim, com teus sorrisos,

Dos sítios, que eu cantei, requinta as graças;

Forma hum Povo feliz de tantos Povos;

Aos campos abundancia restitue,

E restitue ás ondas o commercio:

Hajao da tua mão, propicio Nume,

Os dois Mundos socego, as Artes vida. ${ }^{89}$
89. Ibid., p. 145 .

90. Geßner (1990).

91. Sckell (1790).

92. Rancière (2020, p. 13)

93. Além disso, o poeta alemão acompanhou a execução de projetos de jardins significativos em diferentespartes da Alemanha, como o Tiefurt, localizado em Weimar, e Wörlitz do príncipe Leopold Friedrich Franz von Anhalt-Dessau.

\section{GOETHE E O JARDIM COMO EQUILÍBRIO ENTRE A ARQUITETURA E A POESIA}

No transcurso da segunda metade do século XVIII, logo depois que Alexander Gottlieb Baumgarten havia firmado a estética como a ciência do sensível, os territórios de língua alemã presenciaram o começo de um amplo debate cultural em torno da pintura de paisagem e da arte do jardim. Escritos como os de Salomon GeßnerPintura de paisagem (Landschaftsmalerei ${ }^{90}$ - e do arquiteto Friedrich Ludwig von Sckell - Contribuições à arte do jardim pitoresco (Beiträge zur bildenden Gartenkunst)|91 - procuraram esclarecer o papel daquelas categorias no universo da criação humana e da imitação da natureza. De todas as obras publicadas naquela cronologia, sem dúvida alguma a monumental teoria do jardim de Hirschfeld sobressai sobre as demais, alcançando maior impacto, positivo e negativo, entre os críticos, filósofos e artistas de sua época (Figura 8). O reconhecimento da teoria chegou rápido na França, sendo traduzida pouco tempo depois para o francês. ${ }^{92}$

O jovem Goethe não esteve alheio a esse debate e à subsequente crítica. ${ }^{93}$ Seus poemas e romances põem luz num espírito atento à paisagem e ao jardim como manifestações da sensibilidade e da arte. O romance epistolar Os sofrimentos do jovem Werther toma a natureza, a jardinagem e a contemplação, sobretudo nas cartas iniciais da primeira parte, como fenômenos essenciais à conjugação da alma com o mundo envolvente. A primeira carta - de 4 de maio de 1771 - chama 
94. Adler considera que o atributo "nenhum jardineiro cientista" se refira ao trabalho de Hirschfeld, Das Landleben (A vida no campo), publicado em $1767 \mathrm{e}$, provavelmente, lido por Goethe. Embora Das Landleben exalte cenas pastorais e os benefícios morais da vida simples do campo, seu conteúdo racionalista, próprio do Iluminismo, catalogou a paisagem em diferentes modalidades de acordo com os efeitos provocados no espectador. De certa forma, o jovem Goethe, afeito à estética do movimento Sturm und Drang, renunciava às sistematizações catalográficas, como sugerem as imagens da Enciclopédia de D'Alembert, as quais apresentam a arte e a natureza como máquina funcional. Cf. Adler (1998, p. 71-119).

95. Goethe (2009, p. 14).

Figura 8 - Frontispício do primeiro volume da Theorie der Gartenkunst (Teoria da arte do jardim) de Christian Cay Lorenz Hirschfeld, 1779-1785. Fonte: Hirschfeld (1779). a atenção para um jardim-paisagem criado pelo conde M., por meio do qual foi possível, aos olhos de Werther, tornar a região em um perfeito idílio nos moldes daquele poetizado por Geßner. O jardim era simples, sem a pompa cerimonial do jardim francês, pois se tratava de uma obra elaborada por mãos sem especialidade técnica - "nenhum jardineiro cientista"94 -, mas por um "coração sensível que queria gozar o prazer de estar consigo mesmo". .5

\section{$\mathfrak{S} \mathfrak{l} \mathfrak{e} \mathfrak{D} \mathfrak{i} \mathfrak{i} \mathfrak{e}$ \\ Der \\ (b) $\mathfrak{a} \mathfrak{i} \mathfrak{f} \mathfrak{e} \mathbb{\|} \mathfrak{f} \mathbb{\|} \mathfrak{\|} \mathfrak{i} \mathfrak{t}$ \\ 2oit}

\section{C. $\mathfrak{C}$. \&. Hirith feld,}

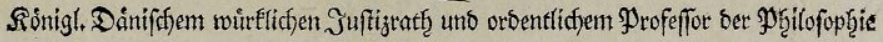
unt ber fdjonen $\mathfrak{2}$ Biffenffifaften auf Der Univerfitåt ju Riel.

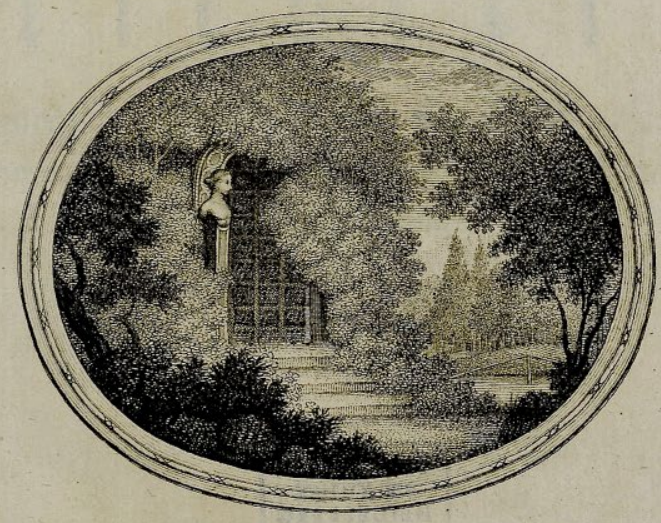

(3) fiter ஒand.

\section{seipzig,}

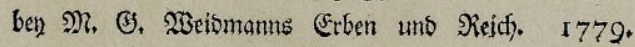


No entanto, uma outra abordagem sobre o jardim assoma em As afinidades eletivas, romance que veio a público em 1809, momento em que a estética goethiana primava, dentre alguns aspectos, a compensação das emoções com os fenômenos empíricos. ${ }^{96} \bigcirc$ livro situa a história de um rico casal - Charlotte e Eduard - que vive dias felizes cuidando do castelo e de seu jardim simétrico, da conversão da região ao redor do castelo em um parque e da construção da nova residência. Eles convidam o Capitão - sujeito perspicaz e comedido, mas ocioso pela falta de trabalho à altura de sua formação acadêmica - e Ottilie, sobrinha de Charlotte, personagem lírica e muito sensível, para compartilharem momentos de alegria no campo e afastados da sociedade. $\bigcirc$ casamento dos anfitriões começa a ruir com a chegada dos novos moradores. Numa espécie de reação química de "afinidades eletivas", Eduard se apaixona perdidamente por Ottilie, enquanto Charlotte e o Capitão desenvolvem uma discreta relação.

A narrativa especifica as duas representações de jardins conhecidas. No castelo erguido pelos antepassados de Eduard, encontra-se já construído um exemplar "ornamentado à antiga". ${ }^{77}$ Ali trabalhava o personagem Jardineiro que, em consequência da introdução do jardim-paisagem por todas as partes, vaticina a obsolescência de sua ocupação. Esse homem seria um caso exemplar de jardineiro sem especialização científica declarado no Werther, pois, contraditoriamente, o jardim-paisagem requer sofisticado conhecimento botânico para a aclimatação de árvores exóticas; exige intenso trabalho de engenharia tanto para a construção de lagos e muros ha-ha, ${ }^{98}$ assim como para a criação cartográfica segundo a exatidão trigonométrica. Por mais que a teoria contemporânea a Goethe tentasse excluir a dimensão arquitetônica daquele estilo, seu surgimento a preconiza, como fica claro no decorrer do romance.

projeto de um parque de acordo com os princípios estéticos dos "ingleses", 99 como dispositivo de embelezamento da natureza, acompanha boa parte do relato, desde seu estudo preliminar detalhado por Charlotte, passando pelos desenhos do Capitão e assessoria do jovem Arquiteto ao fracasso de sua concretização. Já no primeiro capítulo, Eduard parte ao encontro de sua esposa na cabana de musgo implantada no topo de uma colina. Nessa cena, cuja imagem retrata perfeitamente o mitológico casal Baucis e Filemon, os jovens contemplam a diversidade de quadros da natureza formulados pelo olhar. Eles conversam sobre as possibilidades de transformar a propriedade num grande parque, concordando que novos objetos deveriam ser erguidos e outros preservados, desde que a paisagem resultante mantivesse as características do universo pitoresco e do mundo rural: bosques, promontórios, caminhos serpenteantes, uma igreja de estilo gótico, pontes, lagos, arquiteturas rústicas em pedra e madeira, moinhos, entre outros.
96. Sobre a afinidade coesa entre as dimensões objetiva e subjetiva na obra de Goethe, cf. Molder (1995).

97. Goethe (2008a, p. 164).

98. "Ha-ha" eram valas ou fossos secos que serviam de limite no jardim sem interromper a vista. Buscava-se afastar vacas, ovelhas e outros animais do jardim, mas preservando-os nas áreas que evocassem a imagem de paisagens bucólicas. Foram primeiramente implantados na Inglaterra pelo arquiteto e pintor William Kent. Cf. Moore et. al. (2011, p. 76).

99. Além do designativo jardim-paisagem (Landschaftsgarten e jardin paysager), os críticos e teóricos da Alemanha e da França atribuíram a este modelo o termo "jardim inglês" como indicação de sua origem geográfica. 
100. Sobre a designação "Calendário de Jardim" (Gartenkalender), entende-se como uma modalidade de periódico que congregou características de almanaque com discussões especializadas sobre os temas jardim e paisagem.

101. Cf. Schiller (2004).

102. Cf. Idem (1991).

103. Cf. Benn (1991).

104. Goethe (2008a, p. 156).

105. Goethe (1787, p. 54).

106. Goethe (2008a. p. 56).

107. Cf. Schlick (2000).
É interessante sublinhar que, graças ao contato com Friedrich Schiller, iniciado em 1794, Goethe tenha refletido sobre o panegírico dado à jardinagem inglesa em muitos dos escritos que circularam na Alemanha. Essa suposição é plausivel se cotejada com as ponderações de Schiller sobre o jardim encontradas numa resenha editada para o Calendário de Jardins ${ }^{100}$ de 1795.

Na resenha intitulada Sobre o calendário de jardins do ano de 1795 (Über den Gartenkalender auf das Jahr 1795), ${ }^{101}$ o autor de Don Carlo estabelece uma síntese entre os exemplares em voga. Enquanto o jardim de gosto francês vinculavase à "arquitetura" pairando sobre a rigidez do projeto e sucumbindo às leis do Antigo Regime; o jardim irregular promovia o retorno do homem à sua condição original, "selvagem" ou ingênua, ${ }^{102}$ tomando emprestado a terminologia schilleriana. Schiller pressupõe como solução do impasse a criação de um "jardim-estético", cuja forma expressaria a síntese da norma e a liberdade desregrada que inibe a cultura e a história. ${ }^{103}$ A compensação da "arquitetura" com a "natureza" representa idealmente a arte e a autonomia humana. A resenha ressalta aquilo que é propriamente humano em sua significação, entendimento que aparece nas anotações do diário de Ottilie: "ao indivíduo resta a liberdade de se ocupar com o que o atrair, com o que the der prazer, com o que julgar útil, mas o verdadeiro objeto de estudo da humanidade é o homem". 104

O romance não se posiciona a favor de um tipo de jardim em agravo de outro, como obviamente fez Delille em seu poema. Goethe pondera o excesso de elogios ao jardim paisagístico por meio de construções literárias irônicas ou debochadas inclusive em trabalhos anteriores. Na peça teatral $\bigcirc$ triunfo da sensibilidade (Der Triumph der Empfindsamkeit), o prólogo do quarto ato do personagem Askalaphus - o jardineiro da corte do inferno - ironiza as insistências de uma Lady (clara referência à sociedade inglesa) para que Plutão, o deus dos mortos e da riqueza, tornasse o mundo inferior num imenso parque, à semelhança dos Campos Elíseos da corte celestial. ${ }^{105} \mathrm{O}$ sarcasmo do jardineiro concentra-se particularmente nos materiais escolhidos para "ornamentar" o inferno à moda inglesa: madeira rústica para as pontes; e rochas para as grutas em vez de pedras preciosas e outros minérios relativos ao luxo. A ironia ainda aparece sutilmente na primeira parte de As afinidades eletivas quando Eduard propõe um sarau com "descrições de parques ingleses": "primeiro vamos questionar o assunto em forma de brincadeira; mais tarde levá-lo-emos a sério". ${ }^{106}$

As écfrases do jardim e do parque de As afinidades eletivas resultam do equilíbrio entre os polos empiria e emoção, ciência e natureza. Outros trabalhos seguem essa linha de raciocínio. Além do mencionado estudo de Michael Gamper, o terceiro capítulo do livro de Werner Schlick ${ }^{107}$ elabora um discurso enfocando nos 
aspectos ético e estético do parque imaginado Charlotte e Eduard. A abordagem de Schlick demonstra que a implantação de um parque revela o gosto da aristocracia diletante coeva a Goethe, submetida a modismos de converter grandes áreas em lugares supostamente edênicos. Essa aparência vela as tensões sociais e os dramas familiares cotidianos, claramente expostos nos infortúnios ocorridos na inauguração da pedra fundamental da nova residência, na morte do filho de Charlotte no lago do parque (fruto talvez de um adultério) e na insistência de Eduard pelo divórcio. ${ }^{108}$

Goethe era consciente de que a arte poderia submeter a natureza aos seus desígnios sem, contudo, macular o âmbito divino desta. Isso é sintomático na decisão do casal de construir um parque nos arredores da nova residência e fora do perímetro do antigo castelo. Depois de consultar livros ilustrados com paisagens bucólicas e a carta geográfica da propriedade, eles notaram que o artifício poderia aperfeiçoar e realçar tudo o que havia de bom na natureza prístina. ${ }^{109}$

Não se descartava o sensível, muito menos se ignorava a ciência na produção de jardins. $\bigcirc$ Capitão, talvez o personagem mais racional da obra, que, por vezes, compensou a impetuosidade do espírito de Eduard, ficou encarregado de medir a propriedade, traçar o devido mapa topográfico e executar o projeto de embelezamento do entorno. A planta topográfica, instrumento cultural de teor utilitarista, não eclipsaria a conversão da propriedade em um jardim, isto é, em arte. É possível pensar que o desenho cartográfico seria a representação da paisagem imaginada pelos personagens e, portanto, um trabalho que também insere sensibilidade em sua exposição imagética.

Para o Capitão, os dois âmbitos alinham-se, como relata o narrador: "houve oportunidade de falar sobre a região, sobre os planos de ajardinamento, que depois desta vista [mapa] poderiam ser mais bem executados, do que apenas através de tentativas isoladas, baseadas em impressões fortuitas". 110 Na perspectiva do Goethe de 1809, a aparência da paisagem ocorre tanto por vias subjetivas como científicas. ${ }^{11}$ Nos argumentos do Capitão sobressaem o entendimento da natureza circunscrito à técnica e racionalidade iluministas. Depois que ele decidiu se afastar da companhia de seus amigos, em razão das reações contrárias advindas dos laços afetivos criados no castelo e do novo posto recomendado pelo Conde, os trabalhos de ornamentação da propriedade passaram a ser dirigidos pelo personagem Arquiteto, não por um "paisagista" ou "jardineiro", como incentivavam os teóricos ingleses e franceses defensores do discurso estético-ético do jardim-paisagem. Com efeito, o projeto do parque é um objeto que expunha o predomínio da arte sobre a natureza, mesmo que aquela emule a liberdade das formas desta.

Enquanto o jardim do castelo aparece submetido à observação no nível do chão, o parque é contemplado do alto, ampliando-se num panorama. A estética da "vista do alto" caracteriza-se, como Gamper"12 refletiu, pela exposição da
108. Ibidem, p. 76 .

109. Goethe (2008a, p. 56).

110. Ibidem, p. 56.

111. Esse aspecto aparece no elogio conferido ao naturalista e amigo do poeta, Alexander von Humboldt, que havia realizado uma expedição científica e artística por quase toda a América espanhola entre 17991804. Para Humboldt, a compreensão da natureza requer especificações lógicas obtidas por meio de rigoroso estudo científico, sem objetar a sensibilidade humana traduzida em poesia, pintura e jardinagem.

112. Gamper (1998, p. 123). 
113. Em $A$ dissertation on oriental gardening, William Chambers (1772, p. 54), arquiteto do rei George III, descreve a simples natureza como essencialmente variada, capaz de provocar efeitos de surpresa e terror no espírito humano.

114. Goethe (2008b, p. 43).

115. Idem (2017, p. 475).

116. Idem (2008a, p. 34).

117. Ibidem, p. 35.

118. Ibid. p. 169. variedade, da surpresa e da unidade configurada pelas partes. ${ }^{113}$ Além de As afinidades eletivas, Goethe utilizou amiúde o panorama em significativos textos. Em Sobre a arquitetura alemã, curto ensaio escrito em 1772, o jovem poeta e estudante de Direito relata a experiência de liberdade vivenciada no alto do campanário da catedral de Estrasburgo. ${ }^{114}$ Idêntica sensação descreve Fausto na cena do quarto ato. O protagonista, na companhia de Mefistófeles, reitera a autonomia, a liberdade e o gênio criativo do homem relacionando-os à percepção de varredura ocular ao longo do vasto oceano. ${ }^{115}$

No dia da chegada do Capitão ao castelo, Charlotte e Eduard o convidaram a percorrer os espaços que decidiram ajardinar. Mas seria do alto, onde aquele homem apreenderia o significado do jardim idealizado pelo diletantismo da esposa. De cima a vista "é mais livre, e o peito se amplia". ${ }^{116} \mathrm{Em}$ seguida, o narrador descreve o panorama observado pelos três personagens, revelando-se uma pintura de paisagem:

E assim, passando sobre os rochedos, através de moitas e arbustos, chegaram ao último pico [...] $\bigcirc$ vilarejo e o castelo tinham ficado para trás e não eram mais visíveis. Avistavam-se ao fundo extensas lagoas; mais além, colinas verdejantes... e, finalmente, rochedos íngremes, verticais, limitando decisivamente o último espelho d'água, cuja superfície refletia suas formas imponentes. Lá no desfiladeiro... havia um moinho meio escondido que, incluído os seus arredores, parecia um afável refúgio. Em todo o semicírculo que a vista abrangia, alternavam-se ininterruptamente vales e elevações, bosques e florestas, cujo primeiro verdejar prometia para breve um panorama ainda mais exuberante. ${ }^{117}$

A sugestiva visita de um Lord inglês realça o posicionamento de Goethe acerca do equilíbrio entre sensibilidade e razão como intrínseca ao projeto de jardins e parques. Trata-se de um sujeito assemelhado ao Capitão, preocupado com a estética da natureza a partir do inquérito científico. A fim de desenhar as vistas pitorescas do novo jardim, o inglês se ocupou todo o dia com uma câmara escura portátil, aparelho que havia revolucionado a maneira de captar e representar o mundo para além da perspectiva. Ele chegou ao castelo no período em que Charlotte não tinha mais satisfação com o embelezamento da propriedade devido à decisão de Eduard de se alistar para uma guerra e às paixões de Ottilie por seu marido. Um homem, qualificado como silencioso e solícito, acompanhava o Lord em seu tour.

O olhar treinado do inglês percebeu que o parque se ajustava aos modelos criados em sua terra natal, pois "mal conseguia distinguir o trabalho feito pelo homem da obra da natureza". ${ }^{18}$ Nos lugares que demandavam perspectivas pitorescas, esse personagem sugeriu melhoramentos por meio da introdução de objetos louvados por Delille, como uma gruta que, "desobstruída e ampliada, oferecia refúgio aprazível, 
bastaria abater algumas árvores para que de lá se avistasse uma magnífica massa de rochedos". A imperfeição da natureza é, nesse caso, assinalada pela necessidade de aprimoramento e organização. ${ }^{119} \mathrm{O}$ parque, em sev estado inacabado, carecia de ajuste, alcançado a partir da criação humana e na busca pela ordem do todo, ou seja, do efeito pitoresco quando contemplado do alto.

O Lord viajante conclui suas opiniões pincelando-as com ironia. Ottilie e Charlotte perguntam-no sobre para qual local de suas viagens ele gostaria de retornar. "Acostumei-me a me sentir em casa em toda a parte", afinal é cômodo estar onde os outros já construíram, plantaram e cuidaram. ${ }^{120}$ A crítica de Goethe é destinada ao fervor diletante das viagens pitorescas vulgarizadas em sua época. O Grand Tour de princípio do Setecentos elegia o solo clássico - Grécia e Roma - como destino da formação de jovens artistas e pensadores. As viagens de Winckelmann, Goethe e Moritz são nesse caso exemplares. Porém, a partir de meados daquele século, durante o tempo no qual o jardim-paisagem e a arquitetura gótica ressurgiram como alegorias da origem cultural dos países nórdicos e da natureza, ${ }^{121}$ a aristocracia europeia incluiu novos itinerários, dirigindo-se à Inglaterra ou Irlanda. Não por acaso, o inglês, incomodado com o afluxo turístico aos seus jardins, indaga: "quem desfruta agora minha casa, meu parque e meu jardim? Eu não, e muito menos os meus: hóspedes estrangeiros, curiosos e viajantes intranquilos", 122 principalmente porque não há espírito poético em tal habilidade. ${ }^{123}$

A crítica ao contraditório discurso do jardim-paisagem, isto é, mimesis dos fenômenos da natureza sem negar a técnica no melhoramento desta, aparece em outros trabalhos que circularam na Alemanha. Em 1773, Justus Möser publicou, no jornal Patriotische Phantasie, uma sátira sugestivamente intitulada $\bigcirc$ jardim inglês (Das englische Gärtgen), 124 por meio da qual se ironiza literalmente a estética do jardim-paisagem e indiretamente o diletantismo de seus criadores. $\bigcirc$ texto de Möser é uma carta fictícia enviada por uma senhora, chamada Anglomania Domen, à sua avó. A narrativa avalia com muito humor a forma do jardim-paisagem e alguns dos seus objetos, como a ponte de madeira, a igreja gótica (aliás o marido da Anglomania se chama Goterich Dom - Catedral Gótical e a chinoiserie do mobiliário muito em moda na Europa. Anglomania convida sua avó a participar de uma viagem que iniciaria na cidade de Scheveligen, passando pela Inglaterra e, quem sabe, terminaria na China.
119. Schlick (2000, p. 155). 120. Goethe (2008a, p. 170). 121. Cf. Lovejoy (1948); Arraes (2020).

122. Goethe (2008a, p. 170). 123. Goethe (2000, p. 408). 124. Möser (1773, p. 281283). 
125. Cf. Jacobs (1960); Kehler (1975); Ljungquist (1984, 2018); Parshall (2007); Barja; Calatrava (2018).

126. Pückler-Muskau (1833). 127. Ljungquist (2018, p. 295).

128. Kehler (1975, p. 174).

129. Cf. Wolfs (2016).

130. Poe (2018a, p. 70).

131. Cf. Jacobs (1960, p. 405).

132. Ibidem, p. 407.

\section{POE: A NATUREZA COMO EXCESSO}

Estudiosos da obra de Edgar Allan Poe afirmam que o escritor se interessou pela estética do jardim e da paisagem a partir da década de 1840, quando obras centrais sobre o assunto apareceram nos circuitos editoriais dos Estados Unidos. ${ }^{125}$ Além de teorias e críticas de origem inglesa ou francesa, como as de Walpole, Gilpin, Uvedale Price e Claude-Henri Watelet, Poe leu o diário do príncipe Hermann Ludwig Heinrich von Pückler-Muskau, ${ }^{126}$ sobre o tour da Alemanha à Irlanda, passando pela França e Inglaterra entre os anos de 1828 e 1829.127 Os escritos do príncipe se tornaram um sucesso nos Estados Unidos nos anos 1830. ${ }^{128}$ Considerado por alguns como diletante, Pückler-Muskau foi o mentor do projeto de um parque em sua propriedade situada na cidade de Bad Muskau e o criador do neologismo Parkomanie ["parque-mania"], 29 léxico alusivo ao pathos do jardim-paisagem na Alemanha contemporânea de Goethe.

O escritor se interessou, destarte, por um universo bibliográfico diversificado. Ao invés de interpretar o discurso do jardim e da paisagem que há nos contos ora analisados - O domínio de Arnheim ou o jardim-paisagem e A cottage de Landor - ilhados em si, seria pertinente abordá-los a partir da intertextualidade teóricoliterária na qual se inseriram. Obviamente sem esquecer de relacioná-los com outras obras do próprio autor que assumem a natureza, a paisagem e o jardim como enunciados centrais de composição poética.

Em 1842, Poe submeteu a resenha intitulada $O$ jardim-paisagem (The landscape Garden) à revista The democratic review. O texto frisa a natureza substanciada por excessos e ofensas suscetíveis de correção. $\bigcirc$ ajuste ocorreria em jardins, objetos pelos quais o autor reivindicou suas musas ou o seu reposicionamento na hierarquia das belas artes: "a meu amigo the parecia que a criação de um jardimpaisagem oferecia à musa apropriada a oportunidade mais magnífica". ${ }^{130}$ Não obstante, os editores optaram por declinar o manuscrito, em razão da publicação no número anterior do periódico de um artigo de tema similar. ${ }^{131}$ Embora a resenha tenha sido inicialmente negada, o jornal Ladies' Companion a publicou em outubro daquele ano. ${ }^{132}$ Tempos depois, Poe ampliou e revisou suas análises sobre a estética do jardim publicando-as no conto $O$ domínio de Arnheim ou o jardim-paisagem.

O domínio de Arnheim está dividido em duas partes complementares. A primeira descreve o personagem principal Ellison, seu posicionamento social, como veio a herdar uma enorme fortuna, as especulações de como o dinheiro seria gasto e seu entendimento sobre o significado de natureza e jardim. Nessa seção é explíita a relação que Poe fez do protagonista com o mercador Thelluson, descrito por Pückler-Muskau em sua viagem: " $V i$, pela primeira vez, um relato deste assunto no 
tour do príncipe Pückler-Muskau". ${ }^{133}$ De acordo com Linda Parshall, os escritos do nobre alemão ofereceu informações literárias a Poe, motivando-o a imaginar o jardim idealizado por Ellison em Arnheim. Numa carta à ex-esposa e amiga Lucie, PücklerMuskau detalha um extenso jardim que the apareceu no itinerário entre Wesel e Arnhem (Arnheim, em alemão). ${ }^{134}$ Outros exemplares são frequentes no relato do príncipe - Kew, Wimbledon Park, Warwick Castle, Kenilworth e Beckford`s Fonthill - este último é mencionado nas entrelinhas do conto e em A cottage de Landor. ${ }^{135}$

Há trechos que se assemelham com o texto "O jardim francês. Carta a um amigo" 136 do Ensaio sobre os jardins de Watelet. Como no relato de Ellison, o remetente da carta descreve paisagens cuja variedade e beleza irrompem no transcurso de uma viagem fluvial. $\bigcirc$ jardim se encontra num vale rodeado por colinas e montanhas de efeitos sublimes. Ele não é um misantropo, mas se mantém próximo da cidade sem recusar a solidão do campo por vezes necessária. Diferentemente de um Werther ${ }^{137}$ que escolheu se afastar definitivamente da sociedade, enclausurando-se em sentimentos conjugados com paisagens idílicas, o personagem de Watelet e, de reboque, o próprio Ellison, veem o mundo urbano como a exposição da cultura e uma dimensão essencial da formação humana.

Ellison era um poeta, não em seu sentido estrito, mas sua vida demonstrou ações deveras poéticas: "compreendia o verdadeiro caráter, os augustos propósitos e a dignidade suprema do sentido poético". ${ }^{138}$ Ele entendia o jardim como a configuração espacial da poesia e admirava o jardim-paisagem, estilo no qual a natureza transmite suas belezas em inesgotáveis combinações cromáticas e energéticas. ${ }^{139}$ Antagonicamente, essa natureza idealizada possui defeitos e excessos cuja retificação ocorre por meio da arte: "não se pode alcançar lugar algum sobre a ampla superfície do mundo natural sem um olho artístico, pois mirando fixamente, se encontra motivos de ofensa no que se denomina composição de paisagem". ${ }^{140}$

tratamento literário conferido à busca da perfeição da natureza é de teor moral. ${ }^{141}$ Para Poe, a "perturbação" (pecado) da relação entre o homem e a natureza divinizada assegurou aos sentidos o vislumbre dos excessos, ou, em seus termos, a morte contemplada nos defeitos da natureza:

Admitamos que a imortalidade terrena do homem fosse a primeira intenção. Então, teríamos a disposição primitiva da superfície da Terra adaptada a esse estado de gozo, inexistente, mas planejado. As perturbações foram os preparativos para sua condição mortal concebida posteriormente. ${ }^{142}$
133. Poe (2018a, p. 66).

134. Parshall (2007, p. 151).

135. Ljungquist (2018, p 297).

136. Cf. Watelet (1774. p. 138-160).

137. Em As afinidades eletivas Goethe havia notado o papel da cidade na formação humana (cultura). O Lord inglês, proprietário de um parque, declarou para Charlotte e Ottilie: "Mesmo com grandes posses, nunca nos sentimos completamente em casa, sobretudo no campo, onde carecemos de tantos hábitos urbanos. $\mathrm{O}$ livro ardorosamente desejado não está à mão, e justamente aquilo de que mais necessitamos foi esquecido" (2008a, p. 170).

138. Poe (2018a, p. 69).

139. Ibidem, p. 70.

140. Ibid. p. 71.

141. Outra abordagem é apresentada por Farr (2004) e Conlogue (2001).

142. Poe (2018a, p. 73). 
143. Cf. Poe (2002, p. 197).

144. Jacobs (1960, p. 408).

145. Poe (2018a, p. 78).

146. Ibidem, p. 79 .

147. Ibid., p. 77
A natureza maculada pela perturbação humana aparece como conteúdo do conto $O$ colóquio de Monos e Una (The colloquy of Monos and Una). Monos ressalta que o conhecimento, o primeiro mal adquirido pela desobediência do homem, fez com que a fisionomia edênica da Terra se deformasse como uma "horrorosa enfermidade". ${ }^{143} \bigcirc$ livre arbítrio do casal perfeito, ou ato de rebeldia como queria Poe, converteu o estado contemplativo e de passividade em momentos de intensa atividade, nos quais a criatividade possibilitaria, ainda que de forma incompleta e artificial, restaurar o paraíso. Nesse aspecto, o jardim seria para Poe, o produto de um ativo envolvimento estético do homem com a natureza. ${ }^{144}$ Ele reconhece a artificialidade do jardim que, mesmo formado por objetos naturais, o transforma em algo muito diferente da natureza. $\bigcirc$ artificial seria a exposição da cultura, aquela perturbação original, travestido em imitação da natureza.

A seguir, o narrador descreve a viagem destinada a procurar a área ideal para construir o jardim de Ellison. $\bigcirc$ trajeto se dá numa pequena canoa à jusante do rio. Nessa segunda parte do conto, o discurso de Poe prioriza determinadas categorias identificadas na crítica e na literatura de jardim do século XVIII. Não surpreende que apareçam termos como "variedade", "pitoresco" e "coup d'oeil" como maneiras de apreender o efeito da paisagem observada. $\bigcirc$ texto não introduz neologismos, mas aceita o léxico atribuído à natureza e à paisagem da Europa, considerada ela mesma como a própria imagem do idílio.

O domínio de Arnheim se encontra próximo de uma cidade, mas sem desprezar o retiro indispensável à reflexão. Ellison opta por uma região fronteiriça, entre a paisagem bucólica e a sociedade urbana: "o caminho habitual a Arnheim se fazia pelo rio. O visitante deixava a cidade na primeira hora. Ao longo da manhã passava por ribeiras de uma beleza tranquila e doméstica, onde pastavam inumeráveis ovelhas de lã branca que salpicavam no verdor dos pastos". ${ }^{145}$ Ele renunciou territórios longínquos, como as ilhas do Pacífico, onde o misantropo facilmente corrompe o retiro desejável em solidão hipocondríaca. ${ }^{146}$ Pode parecer num primeiro momento que Poe apenas tem em mente a cisão entre o urbano e o rural, e considera a paisagem como a edênica transfiguração da natureza. Contudo, a impossibilidade de retornar ao estado primeiro da humanidade, o fez pensar a cidade como indispensável à existência de jardins. E o seu projeto seria irrealizável se o sítio eleito fosse extremamente recôndito: "então busquemos um lugar não muito longe de uma cidade populosa, cujas imediações me facilitam, ademais, levar a cabo meus planos". ${ }^{147}$

O deslocar da canoa pelo rio estimula a visão dos ocupantes a perceber a natureza em paisagens variadas e sucessivas. Enquanto à direita a natureza surge em seu estado original, representada por uma cadeia de altas montanhas "rudes" 
e extremamente arborizadas, à esquerda, "o caráter da paisagem é mais delicado e evidentemente artificial". ${ }^{148}$ Poe delimita então duas maneiras de apreensão sensível da natureza. Na primeira, o sujeito se vê confrontado com objetos sublimes, cujos atributos - irregularidade, imensidão, novidade, originalidade - exercem terror sem ameaçar sua autonomia e liberdade. A segunda se refere ao pitoresco, descrito como delicado e artificial. Sua aparência equivale à pintura de paisagem elaborada nos moldes de Claude Lorrain, pintor que reparou os excessos da natureza em composições harmoniosas. ${ }^{149}$

O outro ensaio - A cottage de Landor. Um caminhante no domínio de Arnheim - está ligado à narrativa de $\bigcirc$ domínio de Arnheim como sugere o próprio título. $\bigcirc$ relator descreve uma excursão solitária feita entre dois condados próximos de Nova York. Devido ao relevo e à estreiteza dos caminhos, ele se perdeu sem saber qual direção tomar ao condado B. A incerteza aumenta em razão da Indian Summer, uma espécie de névoa comum durante os meses de Verão, que dificulta a percepção do espaço. Guiando-se pelos raios de sol que irradiavam entre as árvores, ele consegue alcançar uma estrada aberta através do bosque. A região não era desconhecida, evidente nas pedras da estrada que haviam sido "cuidadosamente colocadas".

A paisagem registrada no conto assume o caráter pitoresco: "uma coisa se tornava mais evidente conforme mirava: um artista, e de olhos muito exigentes para as formas, havia supervisionado todos aqueles arranjos". 150 Admitir a paisagem circunscrita na dimensão da pintura equivale a dar continuidade às reflexões filosóficas e teóricas da arte europeia do século XVIII. Para qualificá-la de pitoresca, Poe recorreu à origem semântica do vocábulo como horizonte hermenêutico: "o verdadeiro sentido do termo italiano". ${ }^{151}$ Segundo Hunt, a palavra pittoresco já era comum na Europa em 1654. Referia-se à técnica de pintura cuja composição escapava os tradicionais princípios estéticos de precisão e regularidade. ${ }^{152}$ Primava-se a harmonia do conjunto valendo-se do uso de formas irregulares e de como os fenômenos da natureza se apresentavam aos sentidos do artista. Poe admite sobre a estética do pitoresco:

Havia poucas linhas retas e nenhuma interrompida. O mesmo efeito de curvatura ou de cor aparecia duas vezes, geralmente, mas não frequentemente, em qualquer ponto de vista. Por todos os lados havia variedade na uniformidade. Era uma peça de "composição", para a qual o gosto mais exigente e crítico dificilmente poderia sugerir uma emenda. ${ }^{153}$

Ainda é sugestivo àquela paisagem pitoresca o uso do neologismo inglês "capabilites", 154 clara alusão a Lancelot "Capability" Brown, protagonista, ao lado de William Kent, da moderna técnica de jardinagem da Inglaterra. De certo modo, 
155. Idem.

156. Downing (1859).

157. Poe (2018b, p. 88$)$.

158. De acordo com Santiago Beruete (2016, p. 372), o vocábulo cottage designa uma pequena habitação, geralmente construída em madeira, situada em área rural e que inclui um jardim criado nos moldes da estética pitoresca do século XVIII.

159. Poe (2018b, p. 88$)$.

160. Ibidem, p. 99. os caminhos curvos percorridos pelo narrador lembram a introdução da serpentina nos jardins de Brown e divulgada "nos livros sobre o jardim-paisagem". ${ }^{155} \mathrm{~A}$ familiaridade de Poe com o vocabulário próprio de tratados e livros de jardinagem demonstra, para além do seu interesse pelo tema, a circulação de ideias estéticas, da Europa para os Estados Unidos, que aliás inspiraram a redação de tratados autóctones, a exemplo da teoria de Andrew Jackson Downing. ${ }^{156}$

A propósito da paisagem contemplada e elaborada de acordo com um processo ecfrástico, o interlocutor a descreve de maneira objetiva e segundo critérios estéticos, isto é, o discurso equilibra a análise criteriosa da geografia física, da vegetação local e dos fenômenos da natureza com impressões sensíveis: "o primeiro coup d'oeil quando o sol se deslizou em direção à posição escrita me impressionou tanto [...] como a cena final de algum espetáculo teatral ou melodrama bem arranjado". ${ }^{157}$

O texto apresenta um sujeito de bom conhecimento botânico, pois sabe diferenciar a diversidade das árvores, das plantas e as flores indígenas das exóticas, sem esquecer de mencionar o nome científico de determinadas espécies. O conto de Poe em questão pauta as aventuras de um caminhante solitário em meio a um grande jardim-paisagem construído de acordo com os princípios formais dos "livros sobre jardinagem paisagística". Determinados elementos naturais e antrópicos são constitutivos daquela modalidade: serpentina, pequenas colinas, diversidade vegetal, bosque e efeito pitoresco.

Enfim chega-se à cottage. ${ }^{158}$ Poe cria um retrato pormenorizado da localização, estilo, implantação e as imbricações do edifício com seu entorno. A maneira de olhar do narrador assemelha-se ao do arquiteto, analítico, arrolando as características exteriores do objeto. São fornecidas informações métricas e a relação proporcional das partes (janelas, portas, telhados e piazzas) com o todo edificado. ${ }^{159}$ Ainda são incluídos os diferentes níveis e ângulos dos telhados e sua tonalidade cromática, um cinza pálido, que "se funde com o intenso verde das folhas do tulipeiro". ${ }^{160} \bigcirc$ caráter daquela arquitetura, muito parecido com os exemplares que ilustram o tratado de Downing, parece indissociável da natureza circundante, já que ambos se completam na formulação de uma imagem pitoresca. Isso transparece na existência de um tronco de pereiro morto diante da cottage revestido de flores de begônia, assim como dos peristilos que estruturam as duas piazzas cobertos de jasmins e madressilvas.

O interior da residência assegura as ponderações anteriores, quer dizer, toda a área percorrida era, na realidade, o jardim elaborado pelo Sr. Landor. Depois de acessar a cottage, o narrador expõe suas impressões sobre os espaços. Inicialmente, percebe-se que não havia ruptura entre os ambientes domésticos e o exterior ajardinado. 
Essas dimensões sintonizam perfeitamente a "graça natural" com a artificialidade do trabalho humano. $O$ interior the causou entusiasmo, um sentimento qualificado de "romântico". Mas, o romântico é, para Poe, essencialmente feminino, pois o que o "homem ama verdadeiramente na mulher é simplesmente sua condição de mulher". ${ }^{161}$

\section{CONSIDERAÇÕES FINAIS}

Na Crítica da faculdade de julgar, Kant situa a arte do jardim subsumida à classificação das artes figurativas, como uma bela composição dos produtos adequada a certa ideia. ${ }^{162} \bigcirc$ filósofo reflete sobre o posicionamento do jardim conforme os princípios literários celebrados no poema de Delille, isto é, disposição de objetos naturais numa aparência pictórica enquanto condição de livre jogo da imaginação. Há, nas entrelinhas desse argumento, uma avaliação negativa do "jardim de gosto francês", obra que prima a transformação radical da natureza a partir das convenções ditadas pela rigidez da geometria regular ou imitação arquitetônica. A obra de Delille e o pensamento kantiano exprimem um novo paradigma em curso na Europa ao longo do século XVIII, relativo à apreensão sensível da natureza e sua aparência como símbolos da liberdade e autonomia humanas. Esse novo entendimento do jardim anuncia uma revolução estética com amostras de matiz político-social enxergadas, sobretudo, nos anos da Revolução Francesa.

O poema "Os jardins" é apenas um caso entre tantos outros do reflexo dessa revolução de duplo significado. Com efeito, a partir da década de 1770 apareceram na Alemanha e França literaturas basilares à construção de jardins nos moldes ingleses. ${ }^{163}$ Eram discursos nos quais a aristocracia e a elite intelectual avessas ao Antigo Regime puderam divulgar sua ideologia antimonarquista e liberal, como transparecem nas palavras do conde de Shaftsbury: "um capricho principesco inventou tudo isso, e a escravidão e dependência da corte mantêm-no vivo". ${ }^{164} \mathrm{Se}$ as formas irregulares e os objetos rústicos dos jardins tornaram-se metáforas da nobreza e da simplicidade natureza, e, portanto, signos da liberdade, os cantos de Delille assumem a aparência de metáfora da metáfora ou a representação de uma sociedade idealmente livre.

contra-argumento desse debate ocorre nas imagens paisagísticas produzidas por Goethe em seu romance As afinidades eletivas. Os processos de construção do parque idealizado pelo diletantismo de Charlotte são metáforas de uma sociedade ainda atada aos velhos costumes sociais, visíveis na permanência
161. Poe (2018b, p. 98).

162. Kant (2016, p. 221).

163. Por exemplo, Morel (1776); Girardin (1777) e Hirschfeld (1779-1785).

164. Apud Bredekamp (2013, p. 8). 
165. Apud Baridon (2018, p. 283).

166. Schlegel (2014, p. 187). de um matrimônio fadado ao divórcio e nas relações extraconjugais mantidas pelos quatro personagens preditas pelo personagem Mittler.

Em termos estéticos, o poeta alemão argumenta com ironia a contradição do jardim-paisagem, o qual, embora queira silenciar sua artificialidade por meio de dispositivos que imitam a natureza, figura-se como produto da ciência e do gênio criativo humano. $\bigcirc$ jardim não deve dispensar seu caráter arquitetônico, nem a sensibilidade daquele que o elabora segundo as formas emprestadas da natureza, senão compensar esses dois âmbitos na sua composição. É nesse estado de equilíbrio entre a arte e a natureza que se alcança a liberdade. $\bigcirc$ argumento goethiano, que será em certa medida o de Edgar Allan Poe, reitera uma natureza substanciada por excessos suscetíveis de aperfeiçoamento. Essa adequação ocorre conforme manipulações sensíveis do poeta, do jardineiro e do pintor.

$\bigcirc$ pensamento de Hegel converge com as proposições de Goethe. Num apêndice de seus Cadernos de Estética, ele declara que o jardim, cujo direcionamento formal toma a natureza como modelo de imitação, resulta de uma contradição da qual escapa toda a solução. Por um lado, há os objetos da natureza livre que devem conservar seu estado original. Mas a naturalidade desaparece no momento em que os objetos se tornam escolhas de uma elaboração artificial: o jardim "não é a natureza no sentido estrito do termo, senão uma natureza transformada pelo homem para satisfazer sua necessidade de um ambiente que seja sua criação pessoal". ${ }^{165}$ Talvez o filósofo considerasse fastidioso movimentarse dentro dos bosques de um jardim-paisagem, pois seus efeitos são de breve duração, sem destinar o espírito ao absoluto. Em contrapartida, o jardim francês, do arquiteto, não separa o homem do humano, porque suas linhas submetem os próprios objetos da natureza aos desígnios da arte.

Enquanto Delille e Poe articulam proposições que tencionam reposicionar o jardim dentro do sistema hierárquico das artes liberais, Goethe o entende como arte desde que não abdique a ciência em detrimento da sensibilidade exagerada, própria, ao seu ver, da aristocracia ociosa e diletante de sua época. Se os três escritores conferem ao jardim, cada um ao seu modo, o qualificativo de arte, August Schlegel nega-o tal status, justamente porque sua forma subsome ou ao universo da arquitetura (geometria, simetria, regularidade) ou aos princípios da pintura (composição, pitoresco, bela irregularidade). ${ }^{166}$

Arte ou não arte, o jardim permanece no imaginário como o lugar simbólico da relação do homem com a natureza e como a evocação nostálgica do Éden, dos Campos Elíseos ou da Idade do Ouro, ideia retomada no corolário programático de cidades e bairros-jardins de princípios do século passado ou nas entrelinhas das imagens dos condomínios fechados da atualidade. 


\section{REFERENCIAS}

FONTES IMPRESSAS

BACON, Francis. The Essays. New York: Charles Schibner's Sons, 1908.

CAMPBELL, Colen. The Vitruvius Britannicus or, the British architect. London: [S. n.], 1725. t. 3.

CHAMBERS, Sir William. A dissertation on oriental gardening. London: W. Griffin, 1772.

DOWNING, Andrew Jackson. A treatise on the theory and practice of landscape gardening, adapted to North America. 6. ed. New York: A. O. Moore \& CO., 1859.

GIRARDIN, Réne-Louis de. De la composition des paysage, ou des moyens d'embellir la Natur autour des Habitations, et joignant l'agléable à l'utile. Paris: P. M. Delaguette, 1777.

GEßNER, Salomon. Briefe über Landschaftsmalerei. In: GEßNER, Salomon. Geßner Werke. Organizado por H. D. Frey. Berlin: Verlag von W. Speman, 1900. p. 277-292.

HAZLITT, William. On a landscape of Nicholas Poussin. In: WALLER, A. R.; GLOVER, A. (eds.). The collected works of William Hazlitt. London: J. M. Dent, 1903. p. 168-174.

HIRSCHFELD, Christian Cay Lorenz. Das Landleben. Leipzig: Siegfried Lebrecht Crusius, 1776.

HIRSCHFELD, Christian Cay Lorenz. Theorie der Gartenkunst. Leipzig: Weidmanns Erben und Reich, 1779-1785. $5 \mathrm{v}$.

HIRSCHFELD, Christian Cay Lorenz. Gartenkalender aus das Jahr 1784. Kiel: [S. n.], 1784.

MOREL, Jean-Marie. Théorie des Jardins. Paris: Chez Pissot, 1776.

MÖSER, Justus. Das englische Gärtgen. In: MÖSER, Justus. Sämtliche Werke. Oldenburg, Berlin: Stalling, 1962. $5 \mathrm{v}$.

PÜCKLER-MUSKAU, Hermann von. Tour in England, Ireland and France in the years 1828 and 1829. Tradução Sarah Augustin. Philadelphia: Carey, Lea \& Blanchard, 1833. 4 v. 
SCKELL, Friedrich Ludwig. Beiträge zur bildenden Gartenkunst. München: Lindauer'sche Buchhandlung, 1790.

SWITZER, Stephen. Ichnographia Rustica: or, the Nobleman, Gentleman, and Gardner's recreation. 2. v. London: D. Browne, 1718.

WATELET, Claude-Henri. Essai sur les jardins. Paris: Prault, 1774.

WHATELY, Thomas. Observations on Modern Gardening. London: Printed for T. Payne and Son, at the Mews-Gate, 1777.

OBRAS DE DELILLE, GOETHE E POE

DELILLE, Jacque. Os jardins ou a arte de aformosear as paizagens. Tradução Manoel Maria de Barbosa du Bocage. Lisboa: Typographia Chalcographica e Literaria do Arco do Cego, 1800.

GOETHE, Johann Wolfgang von. Der Triumph der Empfindsamkeit: eine dramatische Grille. Leipzig: Georg Joachim Göschen, 1787.

GOETHE, Johann Wolfgang von. Johann Wolfgang von Goethe Werke. 9. v. Autobiographische Schriften I. München: Deutscher Taschenbuch Verlag, 2000.

GOETHE, Johann Wolfgang von. As afinidades eletivas. Tradução Erlon José Paschoal. São Paulo: Nova Alexandria, 2008a.

GOETHE, Johann Wolfgang von. Sobre a arquitetura alemã. In: GOETHE, Johann Wolfgang von. Escritos sobre arte. Tradução Marco Aurélio Werle. São Paulo: Humanitas, 2008b.

GOETHE, Johann Wolfgang von. Os sofrimentos do jovem Werther. Tradução Erlon José Paschoal. 7. ed. São Paulo: Estação Liberdade, 2009.

GOETHE, Johann Wolfgang von. Fausto: uma tragédia - segunda parte. Tradução Jenny Klabin Segall. 3. ed. São Paulo: Editora 34, 2017.

POE, Edgar Allan. El coloquio de Monos y Una. In: POE, Edgar Allan. Cuentos. Tradução Julio Cortázar. 4. ed. Madrid: Alianza Editorial, 2002. p. 197-202. 
POE, Edgar Allan. El dominio de Arnheim (El jardín paisaje). In: BARJA, Juan; CALATRAVA, Juan (eds.). Edgar Allan Poe: relatos de vida y paisaje. Madrid: Abada Editores, 2018a. p. 65-84.

POE, Edgar Allan. El cottage de Landor. Un pendant de el dominio de Arnheim. In: BARJA, Juan; CAlATRAVA, Juan (eds.). Edgar Allan Poe: relatos de vida y paisaje. Madrid: Abada Editores, 2018b. p. 85-100.

LIVROS, ARTIGOS E TESES

ADLER; Jeremy. "kein wissenschaftlicher Gärtner...”. Werther's letter of 10 May and his reading of Hirschfeld's Landsleben. In: BATLEY, Edward M. (ed.). German Studies VI. London: Institute of German Studies, 1998. p. 71-119.

ARRAES, Esdras. A paisagem e sua dimensão estética. Princípios: Revista de Filosofia (UFRN), vol. 24, n. 45, 2017, p. 37-57. doi: <doi.org/10.21680/1983-2109.2017v24n45ID12634>.

ARRAES, Esdras. Jardim e paisagem entre a literature e a filosofia. Rapsódia, São Paulo, n. 13, 2019, p. 47- 70. Link: <https://www.revistas.usp.br/rapsodia/article/view/165285>.

ARRAES, Esdras Araujo. Goethe diante de duas catedrais góticas. Arquitextos, São Paulo, ano 21, n. 244.04, Vitruvius, set. 2020. Link: <https://www.vitruvius.com.br/revistas/read/ arquitextos/21.244/7879>.

ASSUNTO, Rosario. Ontología y teleología del jardín. Madrid: Tecnos, 1991.

BARIDON, Michel. Los jardines: paisajistas, jardineros, poetas. Tradução Juan Calatrava, José Luis Lopes Jiménez. Madrid: Abada Editores, 2018. 3 v.

BARJA, Juan; CAlATRAVA, Juan (eds.). Edgar Allan Poe: relatos de vida y paisaje. Madrid: Abada Editores, 2018.

BENN, Scheila. Friedrich Schiller and the English Garden: Üben den Gartenkalendar auf das Jahr 1795. Garden History, Londres, v. 19, n. 1, p. 28-46, 1991.

BENDING, Stephen. Horace Walpole and Eighteen-Century Garden History. Journal of the Warburg and Courtauld Institutes, Londres, n. 57, p. 209-226, 1994. 
BERUETE, Santiago. Jardinosofía: una historia filosófica de los jardines. Madrid: Turner Publicaciones, 2016.

BILMAN, Emily. Modern ekphrasis. Bern: Peter Lang, 2013.

BREDEKAMP, Horst. Leibniz und die Revolution der Gartenkunst: Herrenhausen, Versailles und die Philosophie der Blätter. Berlin: Verlag Klaus Wagenbach, 2013.

CLÉMENT, Gilles. Una breve historia del jardín. Tradução Cristina Zelich. Barcelona: Editorial Gustavo Gili, 2019.

CONLOGUE, William. Working the garden: American writers and the industrialization of agriculture. Chapel Hill: The University of North Carolina Press, 2001.

DISPONZIO, Joseph. From garden to landscape: Jean-Marie Morel and the transformation of garden design. AA Files, Londres, n. 44, p. 6-20, 2001.

FARIELLO, Francesco. La arquitectura de los jardines: de la Antigüedad al siglo XX. Tradução Jorge Sainz. Barcelona: Reverté, 2008.

FARR, Judith. The gardens of Emily Dickinson. Cambridge: Harvard University Press, 2004.

GAMPER, Michael. "Die Natur ist republikanisch": zu den ästhetischen, antropologischen und politischen Kozepten der deutschen Gartenliteratur im 18. Jahrhundert. Wüzburg: Königshausen und Neumann, 1998.

HERMAND, Jost. Rousseau, Goethe, Humboldt: their influence on later advocates of nature garden. In: WOLSHKE-BULMAHN, Joachim (ed.). Nature and Ideology: natural garden design in the twentieth century. Washington, DC: Dumbarton Oaks Research Library and Collection, 1997. p. 35-57.

HUNT, John Dixon. The picturesque Garden in Europe. London: Thames \& Hudson, 2002.

JACOBS, Robert D. Poe's earthly Paradise. American Quartely, Baltimore, v. 12, n. 3, p. 404$413,1960$.

JEANNEL, Bernard. Le Nôtre. Tradução Juan Calatrava Escobar. Madrid: Ediciones Akal, 2003. 
KANT, Immanuel. Crítica da faculdade de julgar. Tradução Fernando Costa Mattos. Petrópolis: Vozes, 2016.

KEHLER, Joel R. New lights on the genesis and progress of Poe's landscape fiction. American Literature, Durham, v. 47, n. 2, p. 173-183, 1975.

THOMAS, Keith. O bomem e o mundo natural: mudança de atitude em relacão às plantas e animais (1500-1800). São Paulo: Companhia de Bolso, 2010

LJUNGQUIST, Kent P. The Grand and the Fair: Poe's landscape aesthetics and pictorial techniques. Potomac: Scripta Humanistica, 1984.

LJUNGQUIST, Kent P. Poe's landscapes, picturesque and ideal. In: KENNEDY, Gerald; PEEPLES, Scott (eds.). The Oxford Handbook of Edgar Allan Poe. Oxford: Oxford University Press, 2018. p. 286-303.

LOVEJOY, Arthur O. Essays in the bistory of ideas. Baltimore: John Hopkins Press, 1948.

LUKÁCS, Georg. Goethe y su época. Barcelona: Ediciones Grijalbo, 1968.

MATTOS, Cláudia Valladão de. A pintura de paisagem entre arte e ciência: Goethe, Hackert, Humboldt. Terceira imagem, Rio de Janeiro, v. 10, p. 152-169, 2004.

MOLDER, Maria Filomena. O pensamento morfológico de Goethe. Lisboa: Imprensa NacionalCasa da Moeda, 1995.

MOORE, Charles W. et al. A poética do jardim. Tradução Gabriela Celani. Campinas: Editora da Unicamp, 2011.

NIEDERMEIER, Michael. Rara zu Theorie des frühen Landschaftsgartens. Zandera, Berlim, v. 9, n. 1, p. 1-18, 1994.

OELSCHLAEGER, Max. The idea of wilderness: from prehistory to the age of ecology. New Haven: Yale University Press, 1991.

PARSHALL, Linda. Hirschfeld, Pückler, Poe: the literary modeling of nature. GHI Bulletin Suplement, Washington, DC, v. 4, p. 149-169, 2007. 
PINHEIRO, Maria Lucia Bressan; D'AGOSTINO, Mario Henrique Simão. A noção de pitoresco no debate cultural das primeiras décadas do século XX no Brasil. Desígnio - Revista de História da Arquitetura e do Urbanismo, São Paulo, v. 1, n. 1, p. 119-128, 2004.

PITTE, Jean Robert. Histoire du paysage français. 2. ed. Paris: Tallandier, 1989.

PORTER, David. Beyond the bounds of truth: cultural translation and William Chambers's chinese Garden. Mosaic: an Interdisciplinary critical Journal, Winnipeg, v. 37, n. 2, p. 41-58, 2004.

POSSIN, Hans-Joachim. Natur und Landschaft bei Addison. Tübingen: Max Niemeyer Verlag, 1965.

RAMOS, Manuel João. Drawing the lines: the limitations of intercultural ekphrasis. In: ALFONSO, Ana Isabel; KURTI, Laszlo; PINK, Sarah. Working images: visual research and representation in Ethnography. London: Routledge, 2004. p. 147-156.

RANCIÈRE, Jacques. Le temps du paysage. Paris: La Fabrique Éditions, 2020.

ROUSSEAU, Jean-Jacques. Julie, or the new Heloise. London: New England University Press, 1997.

ROTH, Ludger. Ästhetischer Holismos: ein neuer Typus philosophischer Theoriebildung nach Kant. Siegen: Tectum, 2014.

SALVÁN, Paula M (ed.). El espíritu del lugar: jardín y paisaje en la Inglaterra moderna. Madrid: Abada Editores, 2006.

SCHILLER, Friedrich. Poesia ingênua e sentimental. São Paulo: Iluminuras, 1991.

SCHILLER, Friedrich. Über den Gartenkalender auf das Jahr 1795. In: SCHILLER, Friedrich. Sämtliche Werke in 5 Bänden. 5. v. München: Carl Hanser Verlag, 2004. p. 884-891.

SCHLEGEL, August Wilhelm. Doutrina da arte: cursos sobre literatura bela e arte. Tradução Marco Aurélio Werle. São Paulo: Edusp, 2014.

SCHLICK, Werner. Goethe's Die Wablverwandschaften: a middle-class critique of aesthetic aristocratism. Heidelberg: Winter, 2000.

SEGAWA, Hugo. Amor do público: jardins no Brasil. São Paulo: Fapesp, 1996. 
THALMANN, Marianne. Der romantische Garten. The journal of English and Germanic Philology, Champaign, v. 48, n. 3, p. 329-342, 1949.

TROTHA, Hans von. Der englische Garten: eine Reise durch seine Geschichte. Berlin: Verlag Klaus Wagenbach, 1999.

VIEIRA, Maria Elena Merege. O jardim e a paisagem: espaço, arte, lugar. São Paulo: Annablume, 2007.

WIEDE, Jochen. Abendländische Gartenkultur: die Sehnsucht nach Landschaft seit der Antike. Wiesbaden: Maxrix Verlag, 2015.

WOLFS, Rein. Parkomanie: ein Rundgang auf Haupt- und Nebenwegen. In: WOLFS, Rein. Parkomanie: die Gartenlandschaft des Fürsten Pückler in Muskau, Babelsberg und Branitz. München: Prestel, 2016. p. 16-22.

WUNDERLICH, Heike (ed.). Landschaft und Landschaften im achtzebnten Jabrhundert. Heidelberg: Winter, 1995.

SITES

GALLICA. Disponível em: <https://bit.ly/3n0OSSf>. Acesso em: 12 abr. 2020.

Artigo apresentado em 12/4/2020. Aprovado em 1/7/2020.

\section{(cc) BY}

